\title{
Timing of hydrocarbon emplacement in ozokerite and calcite lined fractures, Teapot Dome, Wyoming
}

Sean T. Brennan, Kristin 0. Dennen, and Robert C. Burruss

Any use of trade, firm, or product names is for descriptive purposes only and does not

imply endorsement by the U.S. Government

Open File Report 2006-1214

U.S. Department of the Interior

U.S. Geological Survey 


\section{U.S. Department of the Interior \\ Dirk Kempthorne, Secretary}

\section{U.S. Geological Survey \\ P. Patrick Leahy, Acting Director}

U.S. Geological Survey, Reston, Virginia 2006

Revised and reprinted: 2006

For product and ordering information:

World Wide Web: http://www.usgs.gov/pubprod

Telephone: 1-888-ASK-USGS

For more information on the USGS - the Federal source for science about the Earth, its natural and living resources, natural hazards, and the environment:

World Wide Web: http://www.usgs.gov

Telephone: 1-888-ASK-USGS

Any use of trade, product, or firm names is for descriptive purposes only and does not imply endorsement by the U.S. Government.

Although this report is in the public domain, permission must be secured from the individual copyright owners to reproduce any copyrighted material contained within this report. 


\section{Contents}

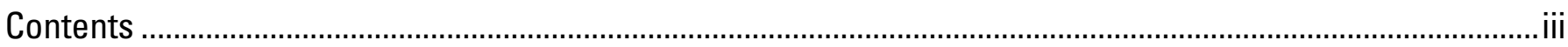

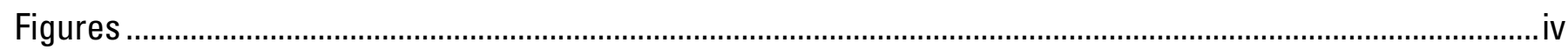

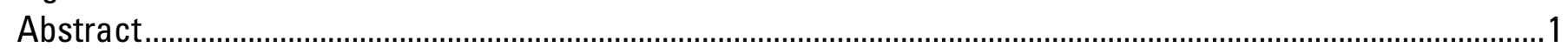

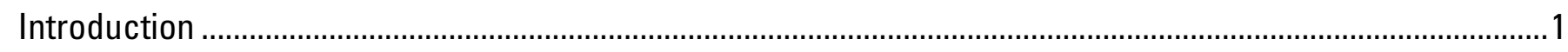

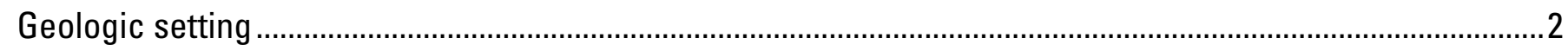

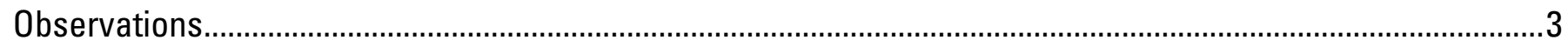

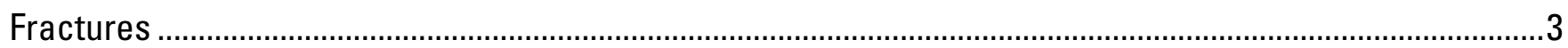

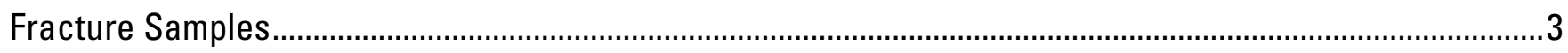

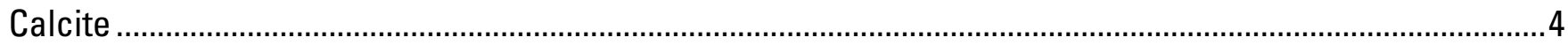

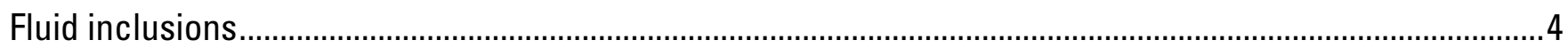

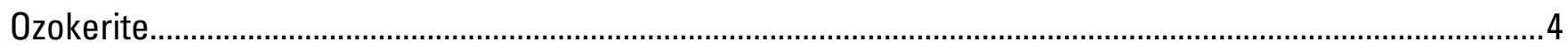

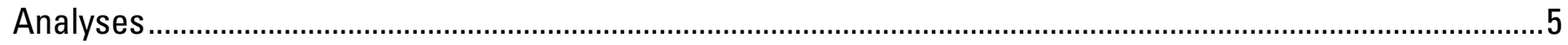

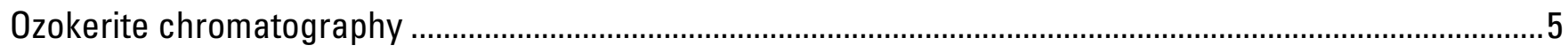

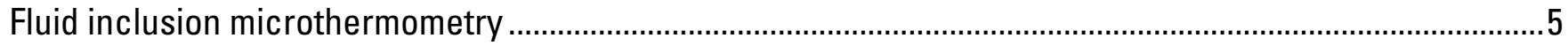

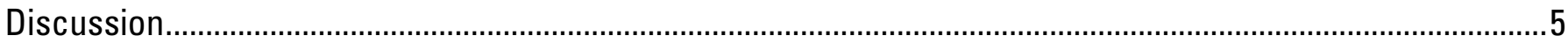

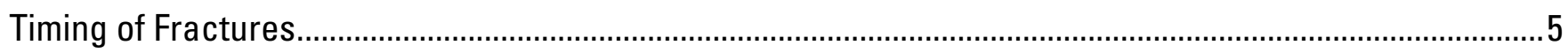

Timing and depth of hydrocarbon fluid inclusion and ozokerite emplacement .........................................5

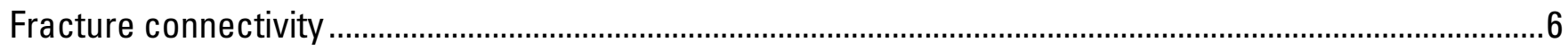

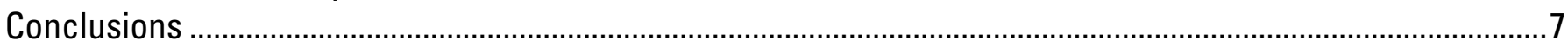

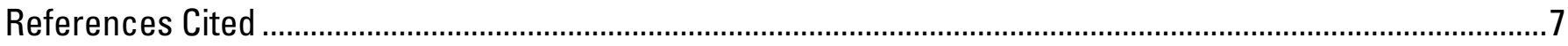

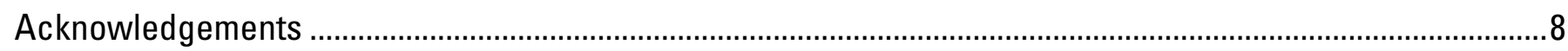




\section{Figures}

Figure 1. Maps show the location of the Powder River Basin, the location of the Teapot Dome field and adjacent Salt Creek field on the western margin of the Powder River Basin in Natrona County, Wyoming (After Dolton and Fox, 1996), and location of the calcite-lined fractures within Teapot Dome.

Figure 2. Stratigraphic column of the Powder River Basin (after Dolton and Fox, 1996). Teapot Dome is along the western margin of the basin. The samples for this study come from fractures within the Steele Shale member of the Cody Shale Formation.

Figure 3. Fracture 1 in outcrop, prior to excavation with backhoe.

Figure 4. Fracture 2 after excavation with a shovel.

Figure 5. Backhoe excavating Fracture 1

Figure 6. Layers of calcite visible in Fracture 2. This fracture is an example of the East West trending fractures ("EWF").

Figure 7. Fracture 1, illustrating the EWF calcite layers cross-cut by ozokerite-lined OFS. Though it is not visible in this image, there is calcite that lines the OFS. In this example the OFS is occluded by the ozokerite.

Figure 8. Ozokerite in Fracture 1. The ozokerite here is brown to amber in color.

Figure 9. (A) Cut face of a hand sample of layered calcite from Fracture 1. (B) The same hand sample under UV light. The layers are more easily observed in the UV light. Furthermore, the calcite layers fluoresce two distinct colors in UV light: a purple color (P), and a blue-green color (BG).

Figure 10. (A) Plane polarized light photomicrograph of fluid inclusions within calcite. Some fluid inclusions (FI) are identified by arrows. Scale bar is $100 \mu \mathrm{m}$. (B) Photomicrograph of the same field of view in UV epi-fluorescence. There are two distinct fluids present in this field of view, hydrocarbon inclusions that fluoresce a blue-white color (FI-B), and others that fluoresce a muted red color (FI-R). Scale bar is $100 \mu \mathrm{m}$.

Figure 11. (A) Plane polarized light photomicrograph of two-phase (liquid and vapor) hydrocarbon fluid inclusions (FI) within calcite. Scale bar is $50 \mu \mathrm{m}$. (B) Photomicrograph of the same field of view in UV epi-fluorescence. These hydrocarbon fluid inclusions (FI) fluoresce a blue-white color. Scale bar is $50 \mu \mathrm{m}$.

Figure 12. (A) Plane polarized light photomicrograph of hydrocarbon fluid inclusions (FI) within calcite. Scale bar is $50 \mu \mathrm{m}$. (B) Photomicrograph of the same field of view in UV epifluorescence. These hydrocarbon fluid inclusions (FI) fluoresce a muted red color. There is a single two-phase hydrocarbon inclusion that fluoresces a blue-white color (FI-B) in the top center region of the photomicrograph. Scale 
Figure 13. (A) Plane polarized light photomicrograph of a thin smear of ozokerite. The ozokerite is translucent, with a slight amber color when it is spread thinly. Scale bar is $200 \mu \mathrm{m}$ (B) Photomicrograph of the same field of view in UV epi-fluorescence. The ozokerite fluoresces a blue-white color similar to one of the hydrocarbon fluid inclusion types. Scale bar is $200 \mu \mathrm{m}$

Figure 14: Ozokerite gas chromatogram, Surface Hydrocarbon Sample, Fracture 1, Teapot Dome field. Selected peak indentifications: $\mathrm{n}-\mathrm{Cx}$, normal alkanes where $\mathrm{X}$ is the carbon number; pr, pristane; ph, phytane.

Figure 15: Sediment extract gas chromatogram, Surface Hydrocarbon Sample, Fracture 1, Teapot Dome field. Selected peak indentifications: $\mathrm{n}-\mathrm{Cx}$, normal alkanes where $\mathrm{X}$ is the carbon number; pr, pristane; ph, phytane.

Figure 16: Ozokerite gas chromatogram, Surface Hydrocarbon Sample, Fracture 2, Teapot Dome field. Selected peak indentifications: $\mathrm{n}-\mathrm{Cx}$, normal alkanes where $\mathrm{X}$ is the carbon number; pr, pristane; ph, phytane.

Figure 17: Ozokerite gas chromatogram, Surface Hydrocarbon Sample, Fracture 2, Teapot Dome field. Selected peak indentifications: $\mathrm{n}-\mathrm{Cx}$, normal alkanes where $\mathrm{X}$ is the carbon number; pr, pristane; ph, phytane. Replicate analysis.

Figure 18. (A) Plane polarized light photomicrograph of fluid inclusions within calcite. Red arrows and numbers indicate homogenization temperatures of the fluid inclusions. Three other inclusions out of this field of view also homogenized to liquid at 62, 62, and 63 degrees celsius respectively. Scale bar is $25 \mu \mathrm{m}$ (B) Photomicrograph of the same field of view in UV epi-fluorescence. These hydrocarbon inclusions are two phase, and fluoresce a blue-white color. Scale bar is $25 \mu \mathrm{m}$ 


\title{
Timing of hydrocarbon emplacement in ozokerite and calcite lined fractures, Teapot Dome, Wyoming
}

\author{
Sean T. Brennan, Kristin Dennen, and Robert C. Burruss
}

\begin{abstract}
Teapot Dome, Wyoming, also known as National Petroleum Reserve 3, is a candidate for a national $\mathrm{CO}_{2}$ storage test site. The oil field in Upper Cretaceous sandstones at Teapot Dome was discovered in the 1880's based on surface occurrences of a waxy hydrocarbon, "ozokerite", within calcite-lined fractures. The goal of this research is to determine if the hydrocarbons resulted from active (i.e. present-day) seepage of the oil reservoirs or from an older episode of local or basinscale fluid flow.

Two generations of fractures and two separate calcite cementation events are recognized in outcrop, and hydrocarbon wax, likely ozokerite, post-dates both calcite generations. The calcite contains two-phase (liquid-vapor), secondary hydrocarbon fluid inclusions that fluoresce a bluewhite color in UV epi-illumination. The ozokerite also fluoresces blue-white, which suggests that petroleum inclusions and the hydrocarbon wax are related. Gas chromatograms (GCs) of ozokerite are consistent with GCs of oils from Upper Cretaceous reservoirs at Teapot Dome, indicating that a connection between the fractures and a hydrocarbon reservoir did exist.

Secondary hydrocarbon inclusions are present in the calcite, which indicates that active oil migration occurred while the fractures were at higher temperatures than surface conditions. Therefore, the oil was emplaced within the fractures when they were between 600 to $1500 \mathrm{~m}$ deep. Furthermore, the ozokerite formed during the uplift and exhumation of the Upper Cretaceous strata at Teapot Dome. The fractures in this study have no active connection to any deeper oil-bearing strata.
\end{abstract}

\section{Introduction}

Teapot Dome and the adjacent Salt Creek field were found on the basis of surficial hydrocarbon shows (Curry, 1977; Thom and Spieker, 1931; Mills, 1923; Wegemann, 1918). Teapot Dome currently is used as an oilfield technology testing center and may become a test facility for the geologic storage of $\mathrm{CO}_{2} . \mathrm{A} \mathrm{CO}_{2}$ pipeline serves the enhance oil recovery (EOR) project at the adjacent Salt Creek field, and this pipeline may be extended to bring CO2 to Teapot Dome for storage tests. However, the presence of hydrocarbons within fractures exposed at the surface is problematic for storing $\mathrm{CO}_{2}$ in the subsurface as it indicates that the fractures were at some point connected to a deeper petroleum reservoir. Therefore, baseline and fluid-flow history studies are needed prior to injection of $\mathrm{CO}_{2}$. The USGS has recently conducted a study at Teapot Dome on fluid communication within reservoirs and between reservoirs (Dennen et al., 2005), as well as between subsurface fluids and the surface. 
The purpose of the research discussed in this paper is to determine if fractures exposed along the crest of Teapot Dome are in active communication with subsurface oil-bearing strata, or when in the past they were connected to deeper formations. The exposed fractures contain generations of calcite, and these cements contain aqueous and hydrocarbon fluid inclusions. The calcite is overlain by a hydrocarbon wax indicating the hydrocarbons were present after the calcite cementation. Therefore, the fractures contain all the information needed to determine the timing of hydrocarbon emplacement, whether it was at depth or when the host shale was exposed. The results can help to determine if these fractures represent an active connection with hydrocarbon reservoirs or a conduit that has not been active since sometime in the geologic past.

\section{Geologic setting}

Teapot Dome is located in the southwestern portion of the Powder River Basin (Fig 1), a deep basin filled by a thick package of Phanerozoic strata $(>5,500 \mathrm{~m})$ that contains a large volume of hydrocarbon resources (Dolton and Fox, 1996). The Powder River Basin has been altered by tectonic activity from Laramide-age orogenesis (Late Cretaceous through Paleocene) through middle Miocene extension caused by uplift that began 10 to 12 Ma (Miller et al., 1992; Christiansen et al., 1992). Teapot Dome (Fig. 1) is one of several faulted anticlinal hydrocarbon fields, which lie along the western and southern margins of the basin (Dolton and Fox, 1996). The field is a section of the Salt Creek anticline that has been separated by faulting into two separate hydrocarbon-bearing fields, the other field being the large Salt Creek field to the north (Thom and Spieker, 1931). The anticlines are cored by thrust faults at depth and exhibit extensional fracturing on the crests and closer to the surface (Dolton and Fox, 1996). The extensional fracturing could be the result of folding associated with the thrust faults, or Miocene extensional tectonism due to the uplift of Teapot Dome, or both.

Teapot Dome is rimmed by outcrops of the Parkman Sandstone Member of the Mesaverde Formation (Upper Cretaceous), and along the crest, the Steele Shale Member of the Cody Shale (Upper Cretaceous) is exposed. The Cody Shale (Fig. 2) is a marine unit that formed in the Cretaceous Western Interior seaway, and the overlying Mesaverde Formation (Fig. 2) was deposited in fluvial, coastal, and marginal marine environments (Nuccio, 1990).

Along the crest of Teapot Dome there are calcite-lined fractures that are present in within Steele Shale outcrops. These fractures have been described as faults, correlative with faults in the rim rocks surrounding the dome, with a throw of centimeters to meters, nearly vertical dips, and a strike of $\mathrm{N} 70^{\circ} \mathrm{E}$ (Wegemann, 1918). Furthermore, the fractures were described having widths ranging from millimeters to $10 \mathrm{~cm}$, and filled by calcite with associated hydrocarbon wax (Wegemann, 1918). This hydrocarbon wax was identified by Wegemann (1918) as ozokerite, which is formed from oil with a high concentration of paraffin, which thickens by evaporation of the volatile components of the oil (Hunt 1996). Mills (1923) observed that the fractures are not completely occluded by calcite, with both fracture and vug-like openings commonly containing some amount of ozokerite. The color of the ozokerite, described as amber to semi-transparent, was interpreted as being due to a lack of asphaltenes in the parent oil (Wegemann, 1918).

Wegemann (1918) hypothesized that the ozokerite was formed from the evaporation of Shannon Sandstone oil as that oil contains a low concentration of asphaltenes and a high concentration of paraffins. The ozokerite from calcite-lined fractures in the adjacent Salt Creek dome is black in color, which Wegemann (1918) interpreted as being sourced from Second Wall Creek oil, which, unlike the Shannon oil, does contain asphaltenes. Wegemann (1918) reports that during drilling in the Steele Shale there were blowouts and that calcite fragments were ejected with 
the oil. Therefore, at depth, these calcite-lined fractures contain liquid oil. The oil produced from these wells also has a high percentage of paraffins (Wegemann, 1918).

The strata of Teapot Dome reached maximum burial depth during the Miocene due to deposition associated with Laramide-age orogenesis (Nuccio, 1990). Nuccio (1990) used a timetemperature model to determine that the maximum burial in this southwestern portion of the Powder River Basin (Fig. 1) was at $10 \mathrm{Ma}$, when the temperatures reached $120^{\circ} \mathrm{C}$ within the Shannon Sandstone bed of the Steele Shale Unit. However, within Teapot Dome, maximum burial of the Shannon Sandstone was approximately $760 \mathrm{~m}$ with maximum temperature of approximately $75^{\circ} \mathrm{C}$ (Hansley and Nuccio, 1992). Apatite fission track analysis results indicate that the Upper Cretaceous rocks of Powder River Basin to the northeast of Teapot Dome cooled below $120^{\circ} \mathrm{C}$ (the annealing temperature of apatite) roughly $12 \mathrm{Ma}$ (Naeser, 1992).

\section{Observations}

\section{Fractures}

Calcite-lined fractures containing a waxy, hydrocarbon residue are present in an area of Teapot Dome known as "Conley Wash". Observations for this study are from two such fractures located at $\mathrm{N}^{\circ} 3^{\circ} 17.391^{\prime}$ and $\mathrm{W} 106^{\circ} 12.603^{\prime}$ ( $\mathrm{NW}^{1} / 4, \mathrm{SW} 1 / 4$, sec. 3, T38N, R78W). One fracture ('Fracture 1') is exposed along the northern wall of the wash (Figure 3) and another ('Fracture 2') is buried near the southern wall of the wash (Figure 4). Fracture 1 was excavated by a backhoe (Fig. 5) in order to obtain fresh samples beneath the talus and below any effects of weathering. Fracture 2 was excavated with a shovel, and was completely buried beneath the modern sediments that lined the floor of the wash.

Two distinct fracture generations are visible in these calcite-lined fractures. The main fracture set trends roughly east-west ('EWF'), normal to the anticline axis, and dips at a high angle to the north. The orientation of the EWF is broadly consistent with other calcite-lined faults within the Steele Shale in Teapot Dome (Wegemann, 1918). The fractures in the study are lined by layers of calcite (Fig. 6) suggest episodic precipitation events. These fractures were likely formed due to extension caused by either the anticlinal folding or the extensional tectonism of the Miocene (Miller et al., 1992; Christiansen et al., 1992).

The EWF are cross-cut by a subsequent, oblique fracture set (Fig. 7). This oblique fracture set ('OFS'), indicates a different direction of stress, and these fractures were likely due to extensional tectonism of the middle Miocene (Christiansen et al., 1992). The OFS cross-cut the calcite layers lining the EWF, and the OFS are lined by calcite as well. The calcite, within both the EWF and OFS, does not completely occlude the fractures; there is still pore space present, which is consistent with previous observations (Mills, 1923; Wegemann, 1918).

\section{Fracture Samples}

Fracture 1 is an example of the EWF cross-cut by the oblique fracture set. (Fig. 7). Fracture 2 is an example of the EWF as well, but it does not exhibit the OFS. (Fig. 6). The centers of both Fractures 1 and 2 are lined by ozokerite, which is amber to black in color (Fig. 8). The ozokerite drapes over the calcite in the pore spaces in the fractures, and lines the OFS in Fracture 1, indicating that the emplacement of the hydrocarbon wax post-dates both fracturing and cementation events. The host rock cross-cut by these fractures has a noticeable hydrocarbon odor and appears to be oil-stained. 


\section{Calcite}

There are layers of calcite lining both types of fractures (Figs. 6 and 9), implying distinct periods of precipitation. In hand sample, the calcite visibly fluoresces different colors when exposed to UV light; the bulk of the calcite, from both EWF and OFS, fluoresces a purple color, but some of the calcite fluoresces a bright blue-green (Fig. 9 b). Typically, the layers of calcite are comprised of crystals that exhibit a bladed, isopachous habit. Some sections of the fractures are occluded by calcite and in these occluded sections of the fractures, the calcite crystals trend towards an equant, blocky habit in the center of the fractures.

In thin section, at least two separate calcite cementation episodes can be identified; these cements are associated with the different generations of fracturing. The calcite that lines the EWF is cross-cut by the OFS, and the OFS is lined by calcite cement. This later OFS calcite cement distinct as it is inclusion-poor and has a muted fluorescence as compared to the inclusion-rich and more fluorescent EWF calcite cement.

\section{Fluid inclusions}

There are abundant secondary hydrocarbon fluid inclusions and primary and secondary aqueous fluid inclusions in the calcite cements. (Aqueous inclusion data are not presented in this report.) Fluid inclusions are small packets of ambient fluid (aqueous, hydrocarbon, $\mathrm{CO}_{2}$, etc.) that are trapped within a crystal. This entrapment occurs either as the mineral is precipitating, which are "primary inclusions" as they are trapped as the mineral is formed, or via the healing of microfractures in the crystal, which are "secondary inclusions" as they post-date mineral precipitation (Goldstein and Reynolds, 1994). The hydrocarbon inclusions are observed only in the calcite cement that lines the EWF. No hydrocarbon inclusions were observed in the calcite that lines the OFS. This observation suggests that the hydrocarbons were likely emplaced within microfractures that were caused by the OFS and that hydrocarbons entered the fractures sometime after that fracturing event.

Two separate hydrocarbon fluid types were observed in these inclusions by UV epifluorescence, one that fluoresces a bright white-blue color and another that fluoresces a muted red color (Fig. 10). The blue-white fluorescing inclusions are two-phase and clear in transmitted light (Fig. 11). The two-phase (liquid-vapor) nature of the blue-white fluorescing inclusions indicates that the hydrocarbons were present at elevated temperatures, i.e. higher than surface temperatures. The red fluorescing inclusions are a dark brown color in transmitted light, and appear to be single phase (Fig. 12).

\section{Ozokerite}

The ozokerite from both Fractures 1 and 2 is amber to black, which differs from previous observations of amber to semitransparent (Wegemann, 1918). However, when the ozokerite is spread thinly as a film (100's of $\mu \mathrm{m}$ ) it lacks any apparent color and is highly translucent (Fig. 13 A). Thinly spread ozokerite fluoresces the same bright blue-white color in UV epi-fluorescence (Fig. 13 B) as the blue-white fluorescing hydrocarbon fluid inclusions (Fig. 11). This similar fluorescence color suggests that the ozokerite and hydrocarbon inclusions suggest that they share a common parent oil. 


\section{Analyses}

\section{Ozokerite chromatography}

Dennen et al. (2005) present gas chromatograms of the ozokerite samples from Fractures 1 and 2 and from hydrocarbons extracted from the oil stained rocks adjacent to Fracture 1 (Figs. 1417). There are measurable peaks for the ozokerite samples from both Fractures 1 and 2; however, the analyses of the ozokerite samples are not identical (Dennen et al., 2005). The ozokerite from Fracture 1 has measurable $n$-alkane peaks in the range $n$ - $\mathrm{C}_{14}$ through $n$-C $\mathrm{C}_{40}$ (Fig. 14). The hydrocarbon residuum extracted from the oil-stained host rock has $n$-alkane peaks in the range $n$ $\mathrm{C}_{14}$ through $n$ - $\mathrm{C}_{40}$ (Fig. 15), which is the same range exhibited by the ozokerite in Fracture 1 (Fig. 14). The ozokerite from Fracture 1 and the extracted hydrocarbons from the oil stained rock have pristane:phytane ratios of 2.2 and 3.8. The ozokerite from Fracture 2 has measurable $n$-alkane peaks in the range $n$ - $\mathrm{C}_{25}$ through $n$ - $\mathrm{C}_{40}$ and no measurable pristane or phytane (Figs. 16, 17), which is different than the results from the ozokerite from Fracture 1, and the extracted hydrocarbons from the oil stained rock.

\section{Fluid inclusion microthermometry}

The hydrocarbon fluid inclusions exhibiting blue-white fluorescence are two-phase, liquidrich secondary inclusions. Inclusions from one secondary fluid inclusion assemblage homogenized to liquid at temperatures that ranged from 62 to $66^{\circ} \mathrm{C}$ (Fig. 18). Homogenization temperatures represent the minimum possible temperature at which the fluids were trapped within the crystal (Goldstein and Reynolds, 1994); therefore, hydrocarbons were present in the fractures at temperatures of $66^{\circ} \mathrm{C}$ or greater. These results indicate that petroleum was emplaced at depth, and did not initially enter the fractures when they were at or near the surface.

\section{Discussion}

\section{Timing of Fractures}

The layers of calcite cement on the EWF likely indicate a series of extensional events that would periodically open the fracture and allow aqueous fluid to flow up the fracture and precipitate calcite. The calcite may have precipitated quickly due to a rapid drop in pressure caused by the opening of the fracture, and the presence of primary aqueous fluid inclusions in these cements is consistent with rapid cementation. According to the time-temperature model of Nuccio (1990), the southwestern portion of the Powder River Basin uplift occurred primarily after $10 \mathrm{Ma}$ and these extensional fractures were likely due to variable stress regimes caused by this uplift. Therefore both of the fracturing events may post-date the middle Miocene.

\section{Timing and depth of hydrocarbon fluid inclusion and ozokerite emplacement}

The emplacement of hydrocarbons within the fractures post-date the calcite within the EWF calcite layers due to the secondary hydrocarbon fluid inclusions. The presence of the hydrocarbon residuum, ozokerite, overlying the OFS calcite layers indicates that the hydrocarbons post-date these fractures and cements as well. The presence of hydrocarbon fluid inclusions in the EWF calcite layers and their absence in the OFS calcite suggests that the microfractures in the EWF calcite layers were caused by the OFS event. The calcite cement lining the OFS likely precipitated 
rapidly due to a rapid pressure decrease associated with the aperture of the fractures widening. Hydrocarbons then entered the fractures prior to the healing of the microfractures within the EWF calcite layers, and as the microfractures healed the hydrocarbons were trapped within the EWF calcite as secondary inclusions.

The time-temperature model and fission track analysis (Nuccio, 1990; Naeser, 1992) indicate that the southwestern portion of the Powder River Basin began cooling and uplift after 10 to $12 \mathrm{Ma}$. The maximum temperature attained by the Shannon Sandstone was approximately $76^{\circ} \mathrm{C}$ (Hansley and Nuccio, 1992). The hydrocarbon inclusions homogenized to a single fluid at temperatures between 62 and $66^{\circ} \mathrm{C}$, which suggests that hydrocarbons emplacement occurred when the host rock was at or near its maximum temperature. The timing of the maximum temperature $(\sim 12 \mathrm{Ma})$ and the timing of extensional fracturing ( 12 Ma) indicate that the hydrocarbon emplacement and OFS fracturing were broadly synchronous.

The hydrocarbon fluid inclusion homogenization temperatures also provide evidence of the depth at which the hydrocarbons were emplaced within the fractures. Hansley and Nuccio (1992) state that the maximum burial of the Shannon Sandstone in Teapot Dome was $763 \mathrm{~m}$, with a maximum temperature of $75^{\circ} \mathrm{C}$. As thermal gradients tend to be closer to $25^{\circ} \mathrm{C} / \mathrm{km}, 75^{\circ} \mathrm{C}$ at $763 \mathrm{~m}$ of depth indicates an abnormally high thermal gradient, which is not explained in Hansley and Nuccio (1992). However, the reported temperature of $75^{\circ} \mathrm{C}$ is consistent with the homogenization temperatures of the hydrocarbon inclusions. The producing zone of the Shannon Sandstone in Teapot Dome is between 90 and $150 \mathrm{~m}$ (Olsen et al., 1993). Therefore, if the parent oil for the ozokerite came from the Shannon, it was likely emplaced at or near maximum burial, when these fractures were roughly 600 to $650 \mathrm{~m}$ below the surface.

\section{Fracture connectivity}

The hydrocarbons were emplaced in these fractures at depth, and there is no evidence of hydrocarbons flowing out of these fractures after exhumation. However, there is evidence that, at depth, calcite-lined fractures within the Steele Shale contain liquid oil trapped at high pressure (Thom and Spieker, 1931; Mills, 1923; Wegemann, 1918). There are reports of well blowouts from these fractures, with high rates of oil flow, and pieces of calcite ejected from the well. The wells that produced from Steele-hosted fractures tended to flow for a short period of time (days), with an eventual cessation of production. That flow history may be the result of several possible scenarios. One is that the fractures are connected to deeper oil bearing strata and after flowing for some time the fracture begins to close off at depth due to decreasing pressure.

Another possibility is that oil flowed into the fractures and their connection to a deeper hydrocarbon reservoir was sealed off due to the structural or diagenetic (occlusion by calcite cement) closure of the fractures at depth. If the fractures closed off at depth, they would have essentially been sealed. If the fractures retained the sealing pressure, they would have become overpressured during uplift, which could have caused the well blowouts during drilling. In this scenario there is no driving force to keep the pressure levels up in order to continue oil flow after the initial pressure is depleted.

The ozokerite likely formed within the fractures during uplift. Ozokerite forms by thickening of a paraffin-rich oil via evaporation (Hunt, 1996). Typically, ozokerite is composed of higher weight $n$-alkanes, which makes the ozokerite found in Fracture 1 anomalous. The hydrocarbon residuum found in Fracture 1 contains primarily higher weight $n$-alkanes, but it also contains measurable pristane and phytane, which are typically absent in hydrocarbon waxes such as ozokerite. The sample from Fracture 2 is a more typical ozokerite as it contains only higher weight 
$n$-alkanes and no measurable pristane or phytane. However, the sample obtained from Fracture 1 was a fresher sample than Fracture 2, as the backhoe was able to dig further through the rock than was possible with a shovel in exhuming Fracture 2. Therefore, it is possible that, with a fresher ozokerite sample from Fracture 2, the chromatograms of the hydrocarbons from Fractures 1 and 2 would look more similar.

As the material from both fractures is very 'waxy' and primarily composed of higher weight n-alkanes, it represents a hydrocarbon wax with properties similar to ozokerite, and is therefore referred to herein as 'ozokerite'. The ozokerite may have formed when the fractures were near the surface, but the depth of formation cannot be determined in this study. The formation of the ozokerite, however, may indicate that the oil in these particular fractures was not flowing and may not have been connected to any subsurface reservoir after the probable sealing of the fractures during uplift in the Miocene. Therefore, it is not likely that there is an active connection between these fractures and any deeper, oil-bearing strata, or that there has been one for some time.

\section{Conclusions}

The fractures were likely formed via extensional tectonism during uplift of Teapot Dome which started approximately 10 to $12 \mathrm{Ma}$. There were two separate stress regimes, one that formed the initial east-west trending fracture set and a second that formed the later oblique fractures. The hydrocarbons entered the fractures after the onset of the oblique fracturing, based on the presence of secondary hydrocarbon inclusions in the calcite associated with the initial fracture set, and not within the later fracture set. Also, ozokerite lines the pore space within both the initial and oblique fracture set, indicating that the hydrocarbon emplacement post-dates both fracturing and cementation events.

Other calcite-lined fractures within the Steele Shale at depth may still be connected to deeper oil-bearing strata. However, there is no evidence that the exposed fractures from this study have any active connection to deeper oil-bearing strata. The two-phase, secondary inclusions indicate that the active connection likely occurred while the fractures were at a higher temperature, and between 600 to $1500 \mathrm{~m}$ deeper than present. The hydrocarbons within the fractures were likely altered to ozokerite during uplift. There is no direct evidence of an active connection with any potential $\mathrm{CO}_{2}$ injection reservoir, and therefore these specific fractures are not likely to be locations of seepage of the injected $\mathrm{CO}_{2}$ to the surface.

\section{References Cited}

Christiansen, R.L., Yeats, R.S., Graham, S.A., Niem, W.A., Niem, A.R., and Snavely, P.D., Jr, 1992, Post-Laramide geology of the U.S. Cordilleran region, in Burchfiel, B.C., Lipman, P.W. and Zoback, M.L. eds. The Cordilleran Orogen; conterminous U.S.: United States (USA), Geol. Soc. Am., United States (USA).

Curry Jr., W.H., 1977, Teapot Dome, Past, Present and Future: The American Association of Petroleum Geologists Bulletin, v. 61, p. 671-697.

Dennen, K., Burns, W., Burruss, R., and Hatcher, K., 2005, Geochemical Analyses of Oils and Gases, Naval Petroleum Reserve No. 3, Teapot Dome Field, Natrona County, Wyoming: U.S. Geological Survey Open File Report (IN REVIEW)

Dolton, G.E., and Fox, J.E., 1996, Powder River Basin Province (033), in Gautier, D.L., Dolton, G.L., Takahashi, K.I., and Varnes, K.L., ed., 1995 National assessment of United States oil and 
gas resources--Results, methodology and supporting data, U.S. Geological Survey Digital Data Series DDS-30, release 2, one CD-ROM.

Goldstein, R.H., and Reynolds, T.J., 1994, Systematics of fluid inclusions in diagenetic minerals: SEPM Short Course, v. 31, p. 199.

Hansley, P.L., and Nuccio, V.F., 1992, Upper Cretaceous Shannon Sandstone reservoirs, Powder River basin, Wyoming; evidence for organic acid diagenesis? AAPG Bulletin, v. 76, no. 6, p. 781-791.

Hunt, J.M., 1996, Petroleum Geochemistry and Geology (Second Edition ed.): New York, W. H . Freeman and Company.

Miller, D.M., Nilsen, T.H., and Bilodeau, W.L., 1992, Late Cretaceous to early Eocene geologic evolution of the U.S. Cordillera, in Burchfiel, B.C., Lipman, P.W. and Zoback, M.L. eds. The Cordilleran Orogen; conterminous U.S.: United States (USA), Geol. Soc. Am., United States (USA).

Mills, R.V.A., 1923, Natural gas as a factor in oil migration and accumulation in the vicinity of faults (with discussion by Leon J. Pepperberg, F. H. Lahee, and K. C. Heald): Bulletin of the American Association of Petroleum Geologists, v. 7, no. 1, p. 14-24.

Naeser, N.D., 1992, Miocene cooling in the southwestern Powder River basin, Wyoming; preliminary evidence from apatite fission-track analysis: B 1917-O, United States (USA), O1O17.

Nuccio, V.F., 1990, Burial, thermal, and petroleum generation history of the Upper Cretaceous Steele Member of the Cody Shale (Shannon Sandstone Bed horizon), Powder River basin, Wyoming: B 1917-A, United States (USA), A1-A17.

Olsen, D.K., Sarathi, P.S., Hendricks, M.L., Schulte, R.K., and Giangiacomo, L.A., 1993, Case of Steam Injection Operations at Naval Petroleum Reserve No. 3, Teapot Dome Field, Wyoming: A Shallow Heterogeneous Light-Oil Reservoir: Society of Petroleum Engineers SPE 25786.

Thom Jr., W.T., and Spieker, E.M., 1931, The Significance of Geologic Conditions in Naval Petroleum Reserve No. 3, Wyoming: U.S. Geological Survey Professional Paper 163, p. 64 pp. Wegemann, C.H., 1918, The Salt Creek Oil field, Wyoming: U.S. Geological Survey Bulletin 670, p. 52 pp.

\section{Acknowledgements}

The people at RMOTC, specifically Steve Hardy, Mark Milliken, and Vicki Stamp, were very helpful in the field, in preparation for our visit, and as facilitators during our field work at Teapot. Also, they provided a backhoe and an operator to us, which was crucial for obtaining the fresh samples needed for this study. Kendra Hatcher assisted Bob Burruss during reconnaissance work at Conley Wash, and helped collect calcite samples for study. Ms. Hatcher also prepared the rock samples for thin sectioning. The manuscript was greatly aided by thoughtful reviews by IMing Chou, Hal Gluskoter, and Jim Coleman. 


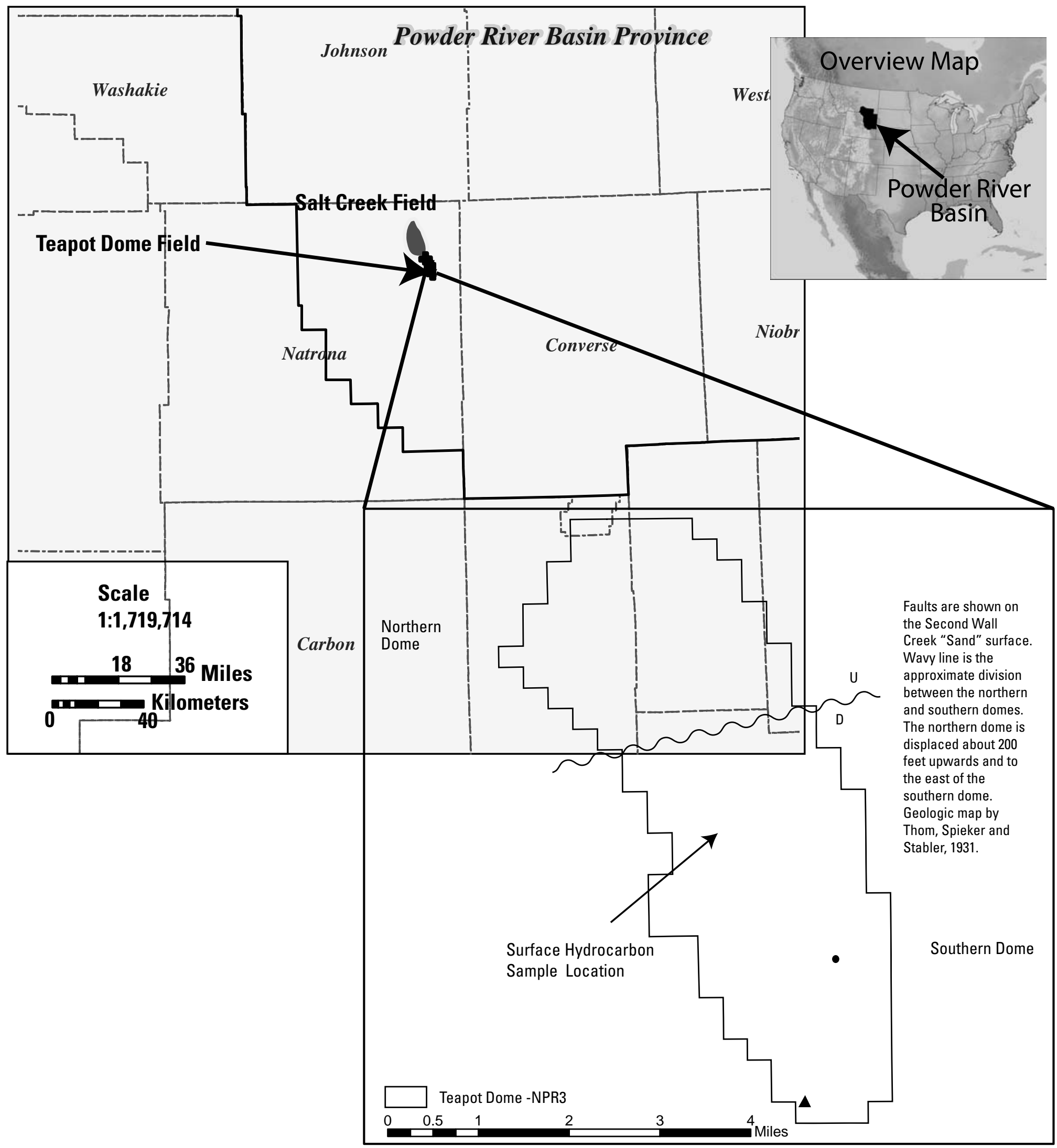

Figure 1. Maps show the location of the Powder River Basin, the location of the Teapot Dome field and adjacent Salt Creek field on the western margin of the Powder River Basin in Natrona County, Wyoming (After Dolton and Fox, 1996), and location of the calcite-lined fractures within Teapot Dome. 


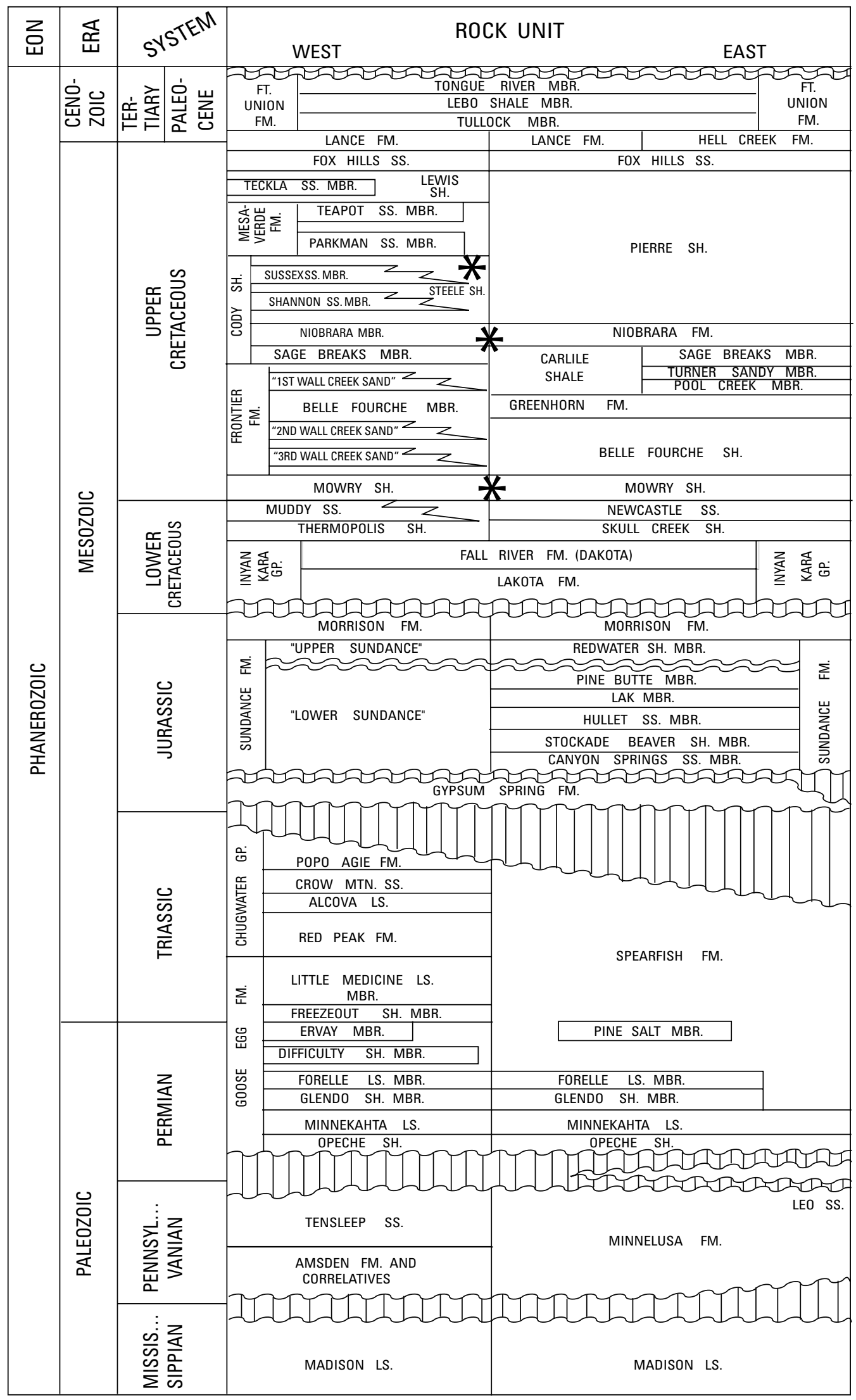

* Hydrocarbon

Figure 2. Stratigraphic column of the Powder River Basin (after Dolton and Fox, 1996). Teapot Dome is along the western margin of the basin. The samples for this study come from fractures within the Steele Shale member of the Cody Shale Formation. 


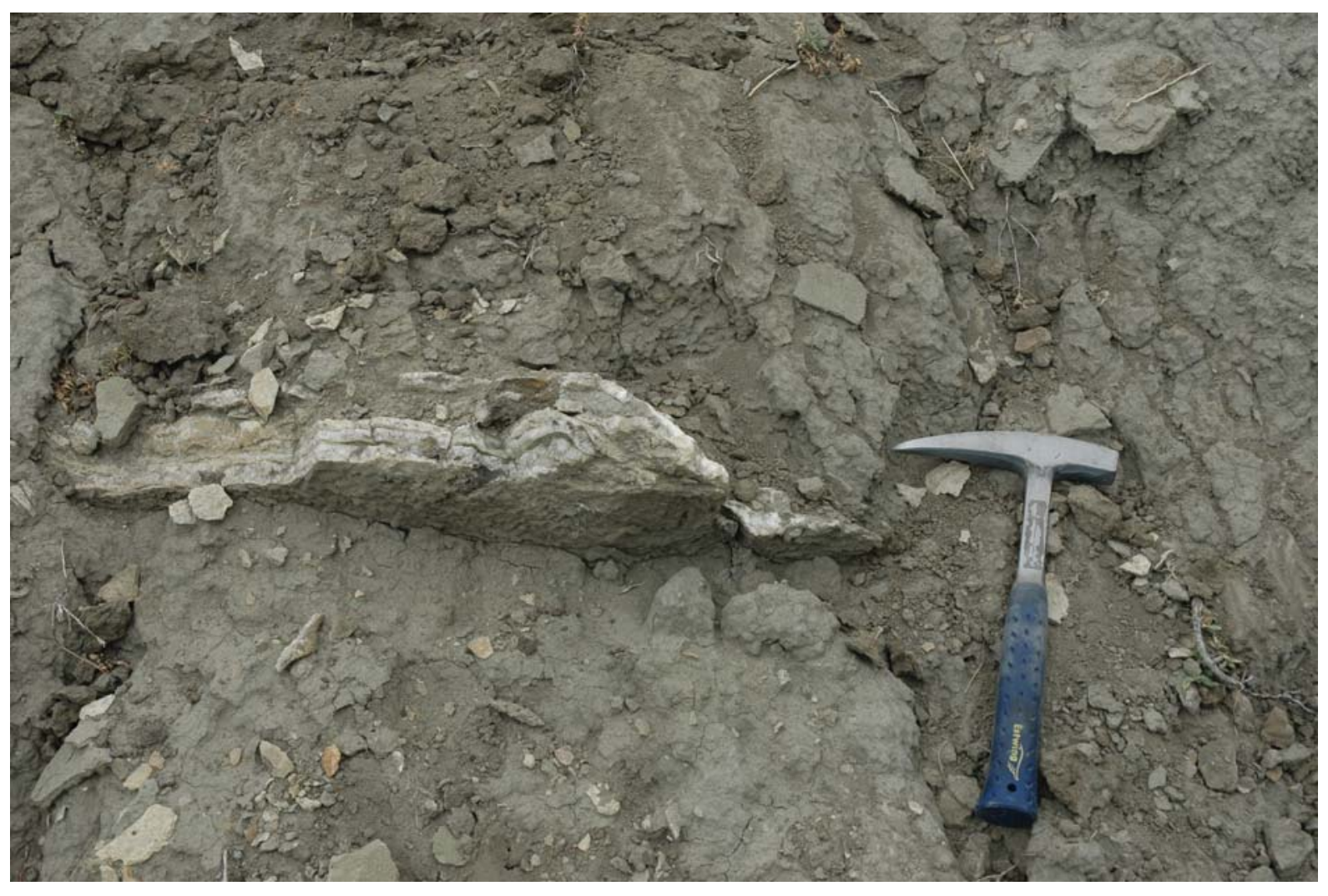

Figure 3. Fracture 1 in outcrop, prior to excavation with backhoe.

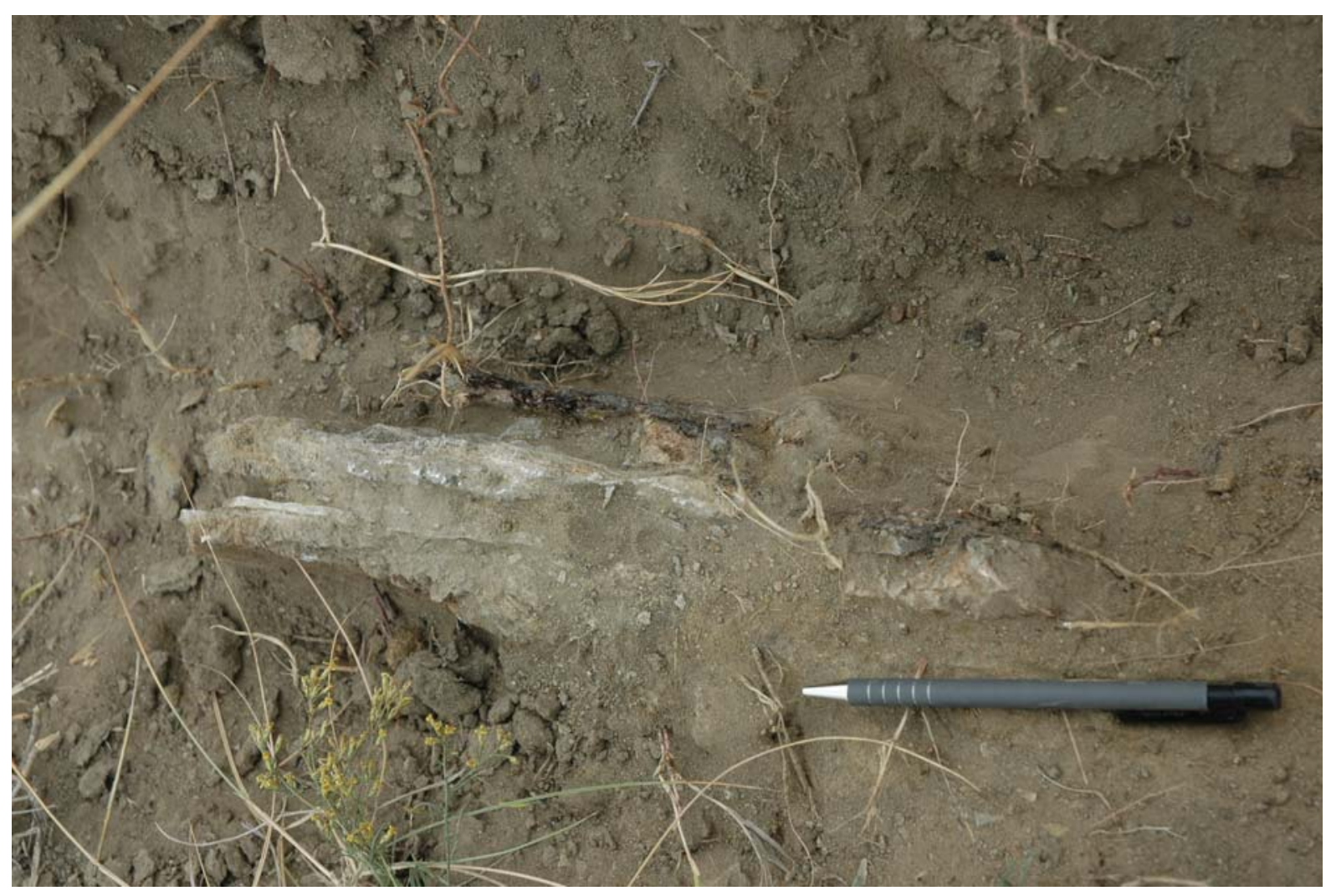

Figure 4. Fracture 2 after excavation with a shovel. 


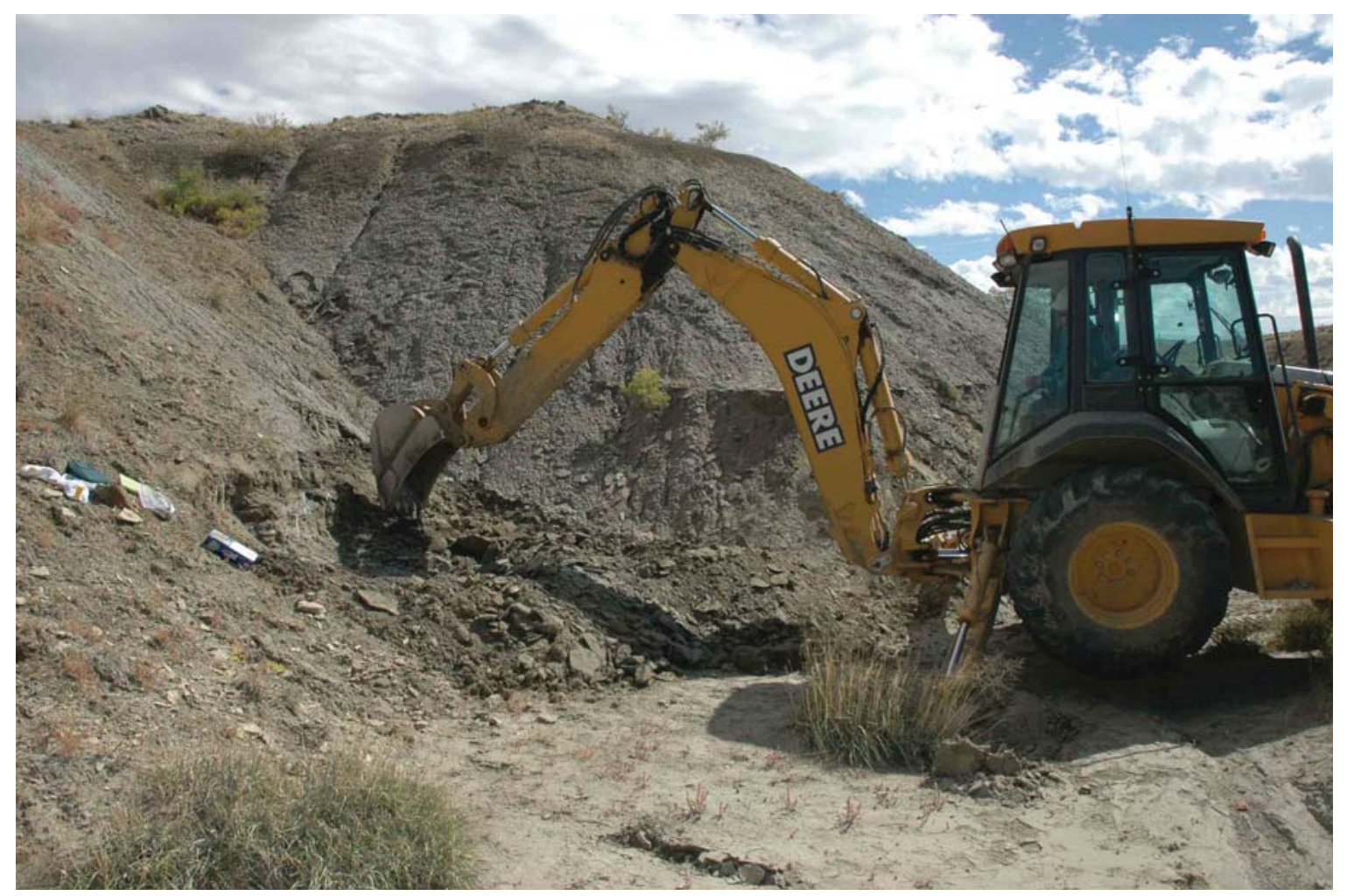

Figure 5. Backhoe excavating Fracture 1

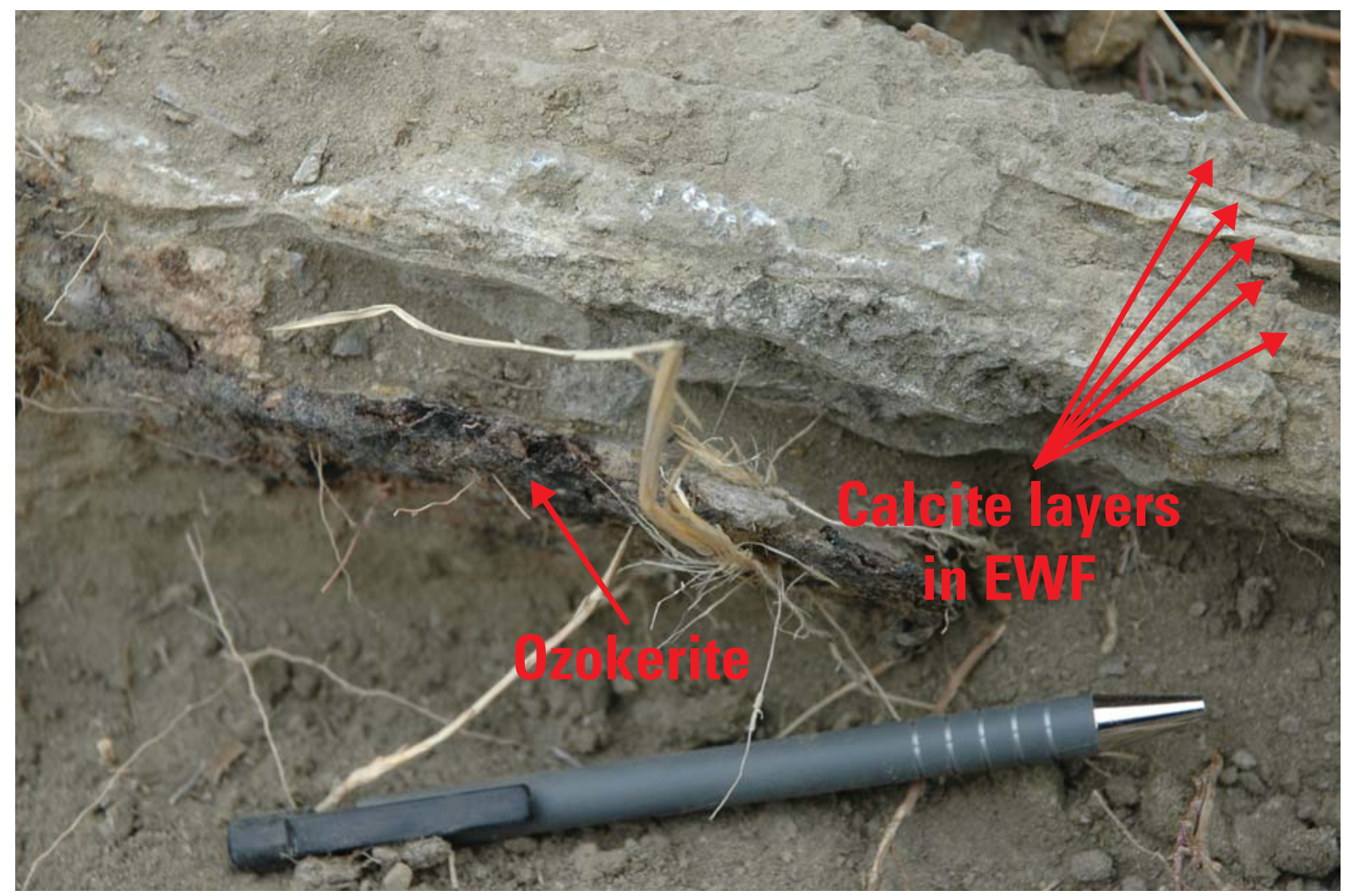

Figure 6. Layers of calcite visible in Fracture 2. This fracture is an example of the East West trending fractures ("EWF"). 


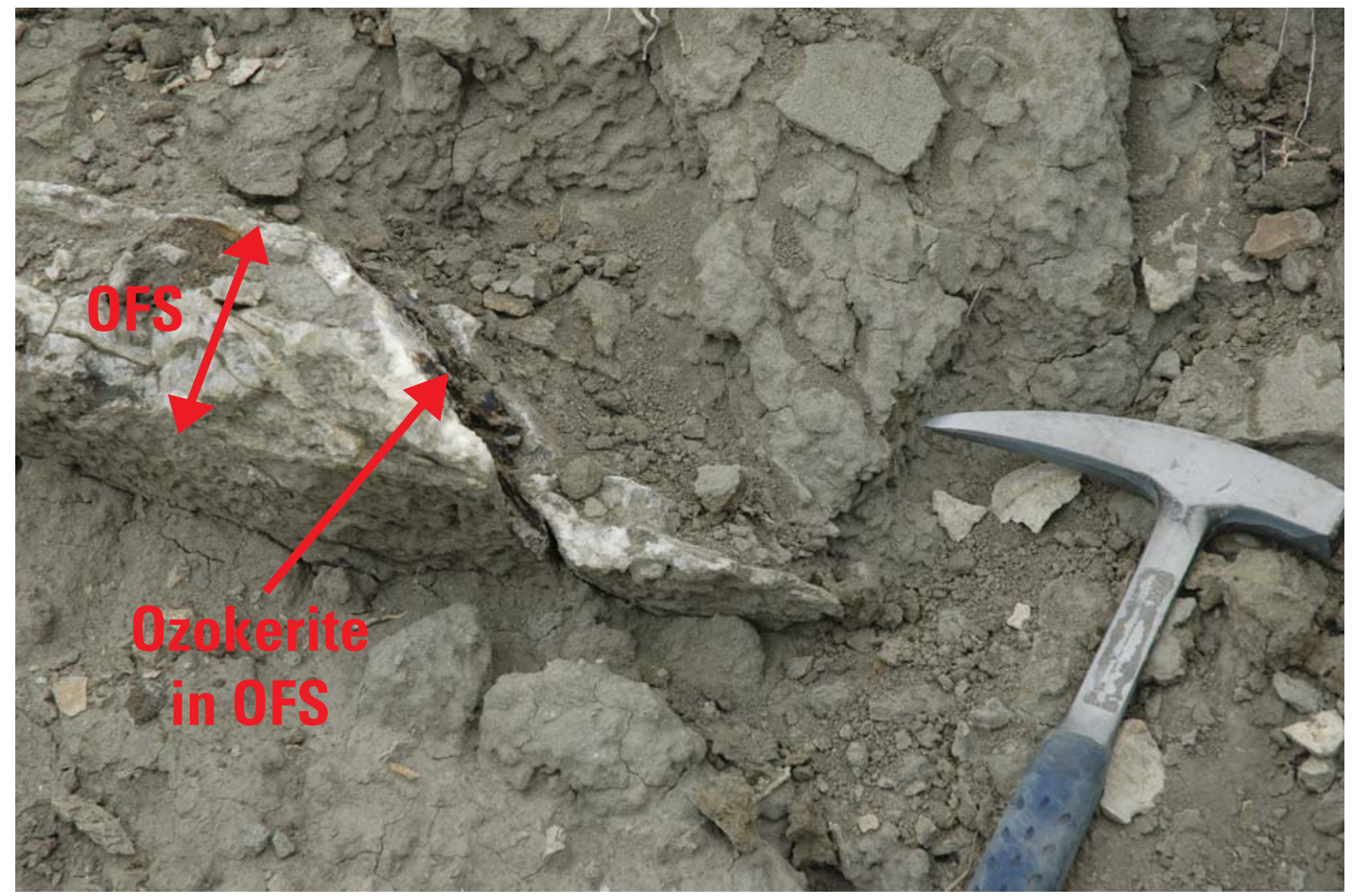

Figure 7. Fracture 1, illustrating the EWF calcite layers cross-cut by ozokerite-lined OFS Though it is not visible in this image, there is calcite that lines the OFS. In this example the OFS is occluded by the ozokerite.

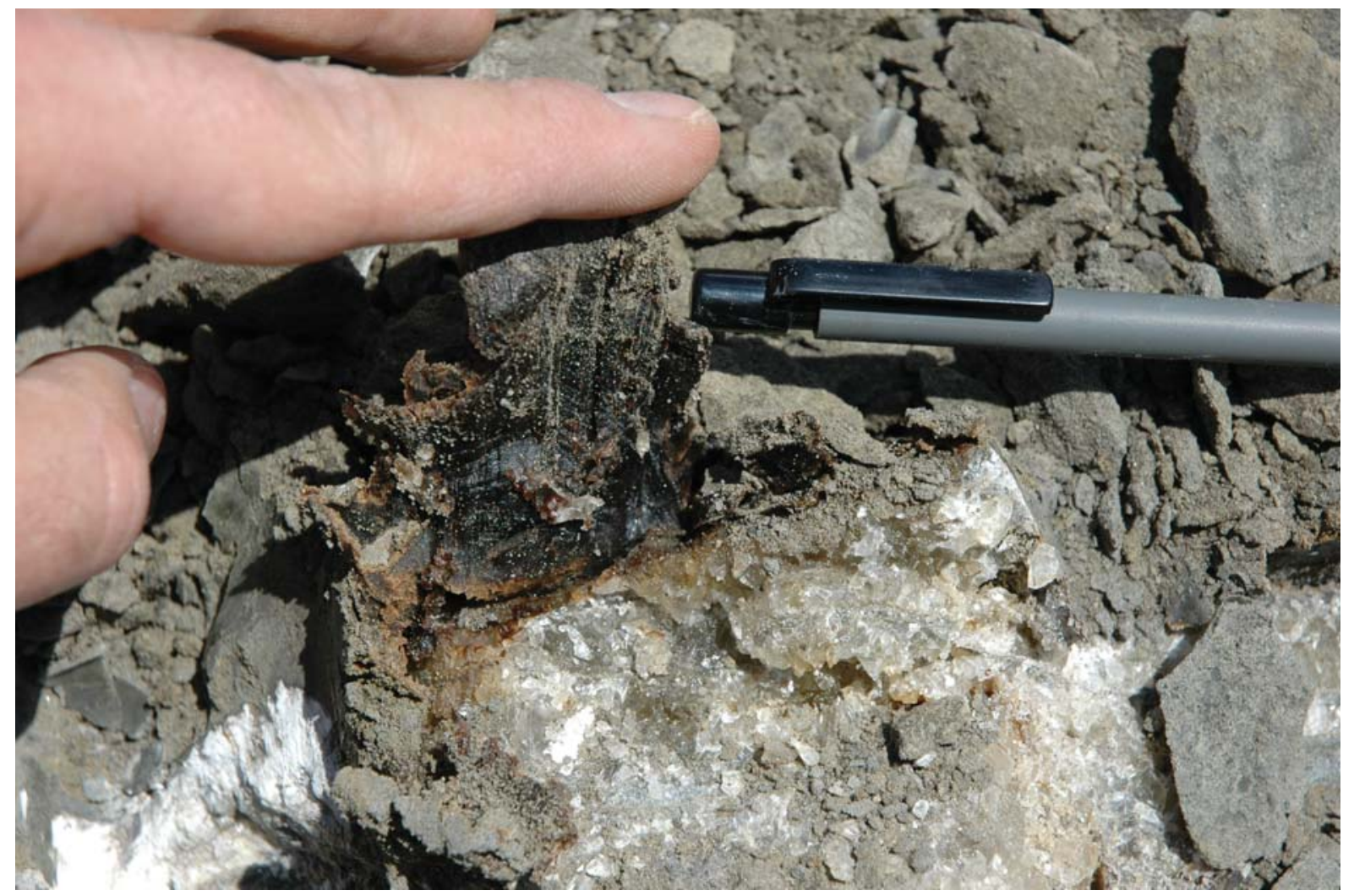

Figure 8. Ozokerite in Fracture 1. The ozokerite here is brown to amber in color. 
A.

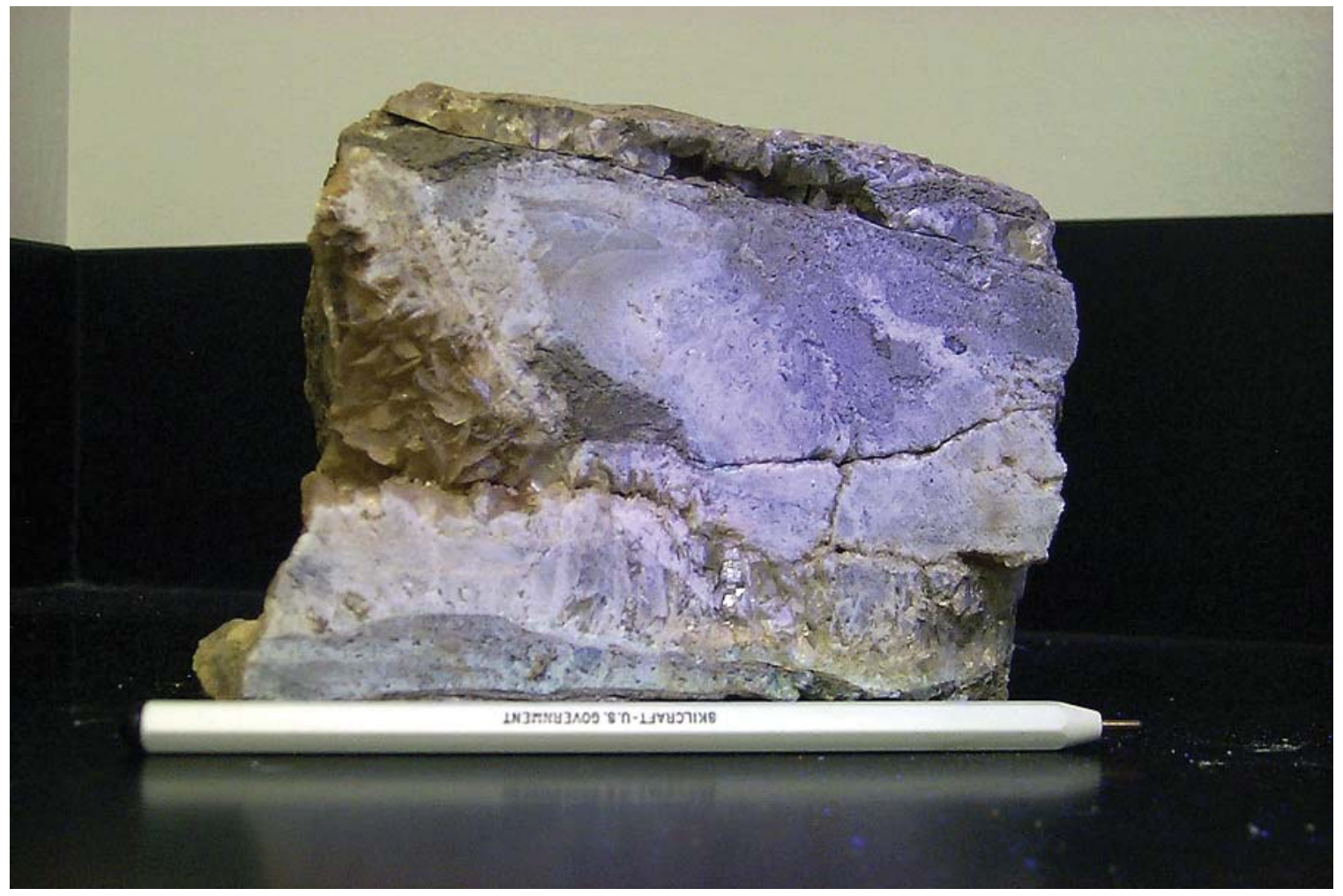

B.

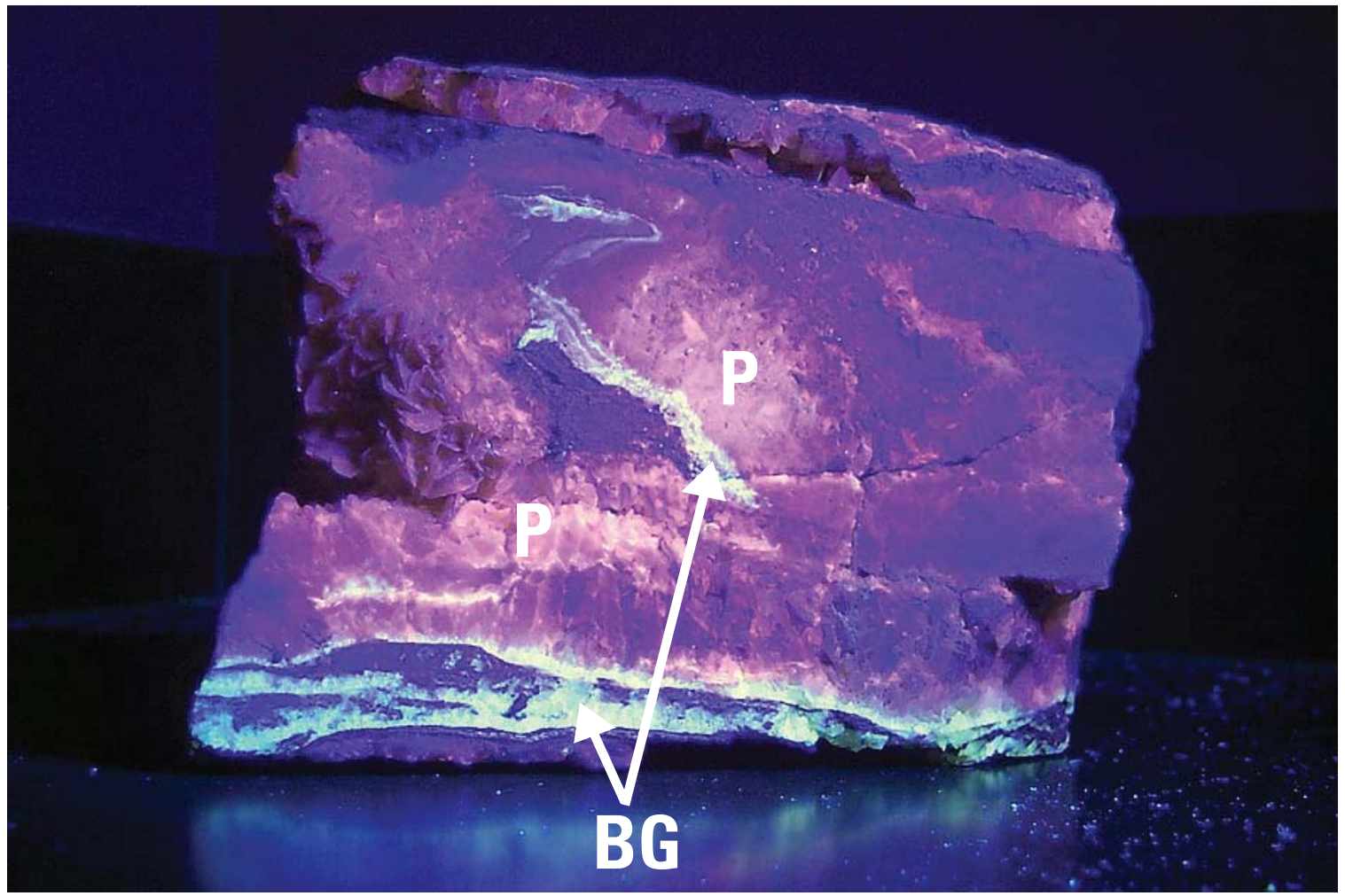

Figure 9. (A) Cut face of a hand sample of layered calcite from Fracture 1. (B)The same hand sample under UV light. The layers are more easily observed in the UV light. Furthermore, the calcite layers fluoresce two distinct colors in UV light: a purple color $(P)$, and a blue-green color (BG). 
A.

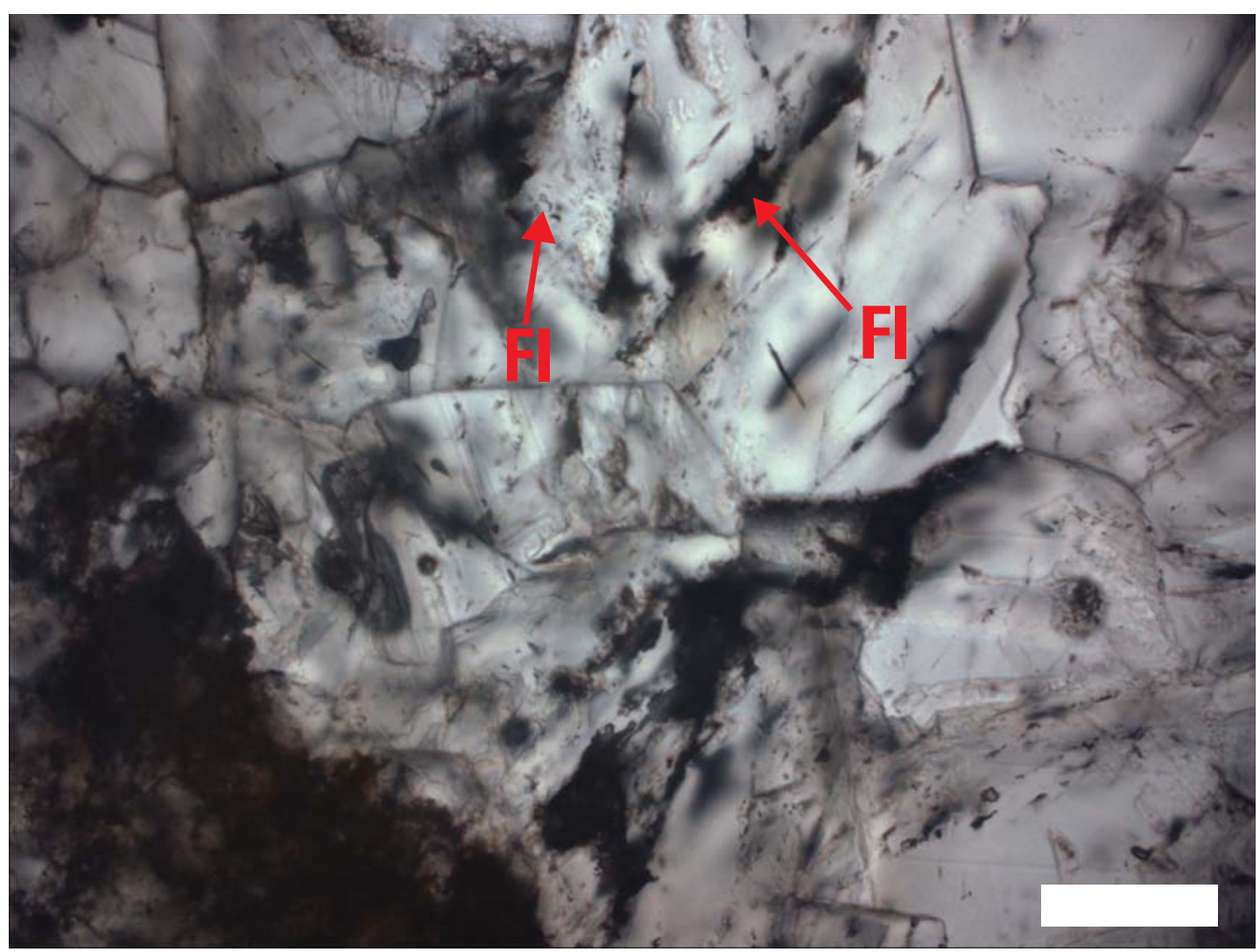

B.

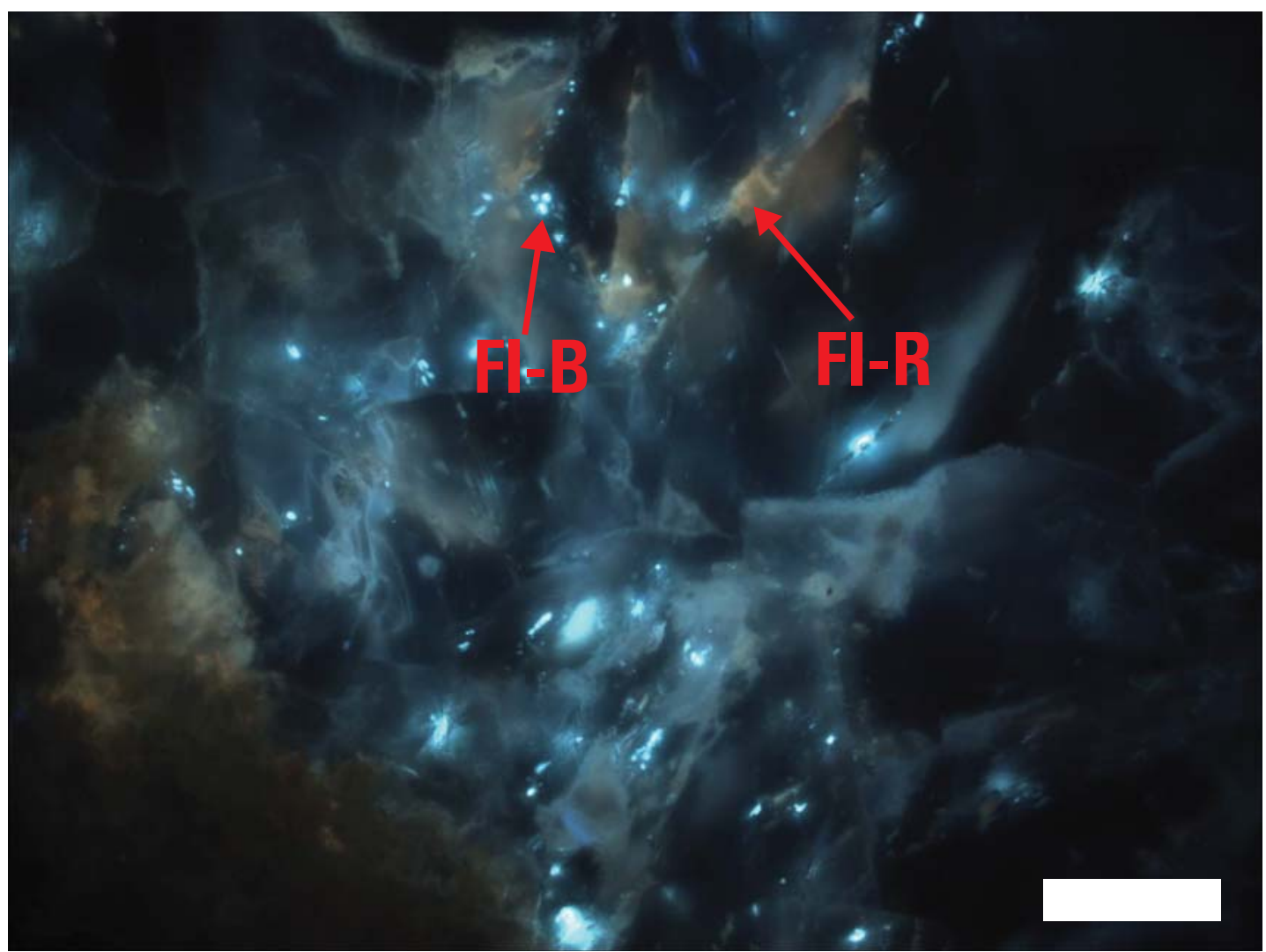

Figure 10. (A) Plane polarized light photomicrograph of fluid inclusions within calcite. Some fluid inclusions (FI) are identified by arrows. Scale bar is $100 \mu \mathrm{m}$. (B) Photomicrograph of the same field of view in UV epi-fluorescence. There are two distinct fluids present in this field of view, hydrocarbon inclusions that fluoresce a blue-white color (FI-B), and others that fluoresce a muted red color (FI-R). Scale bar is $100 \mu \mathrm{m}$. 
A.

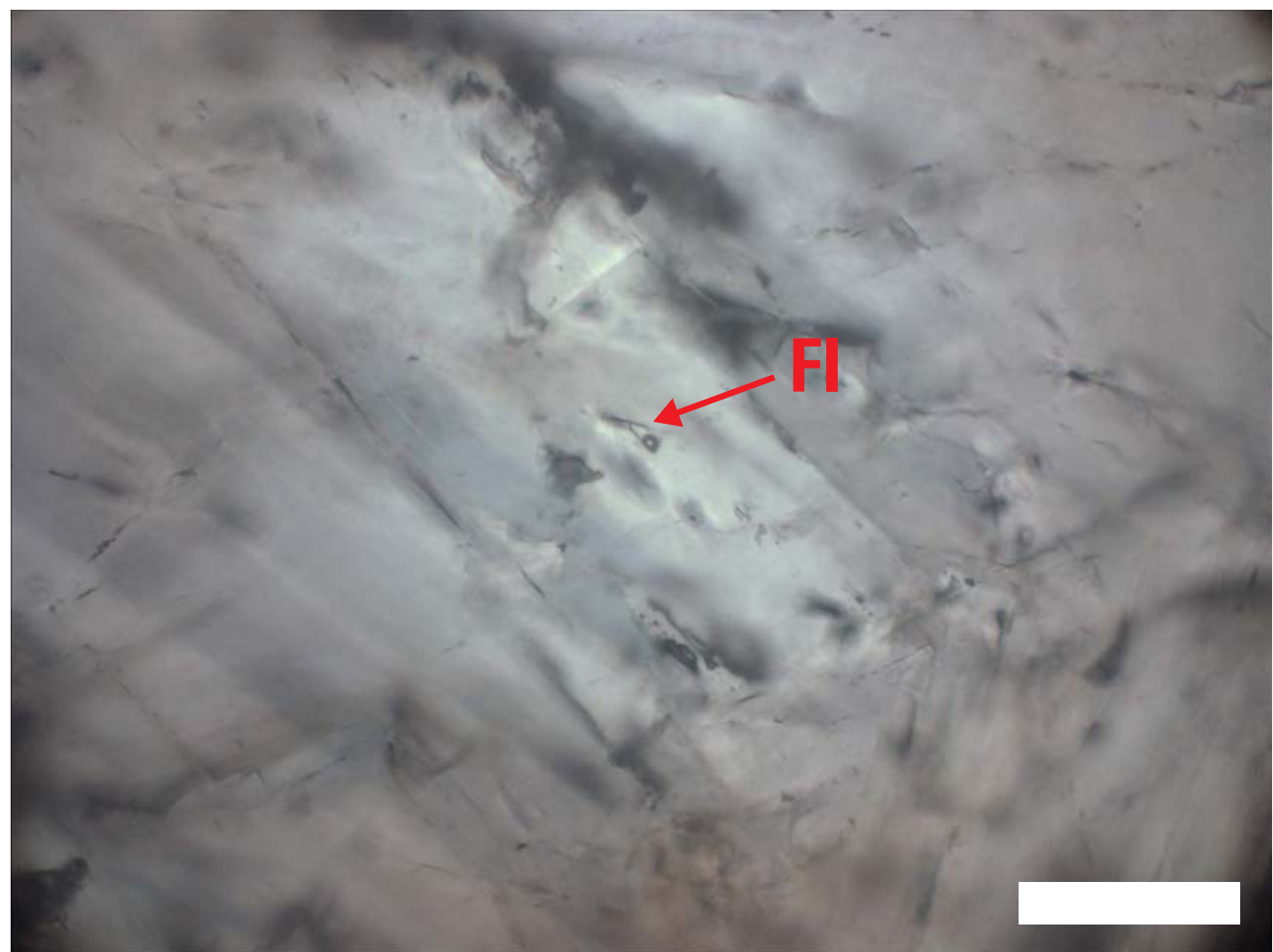

B.
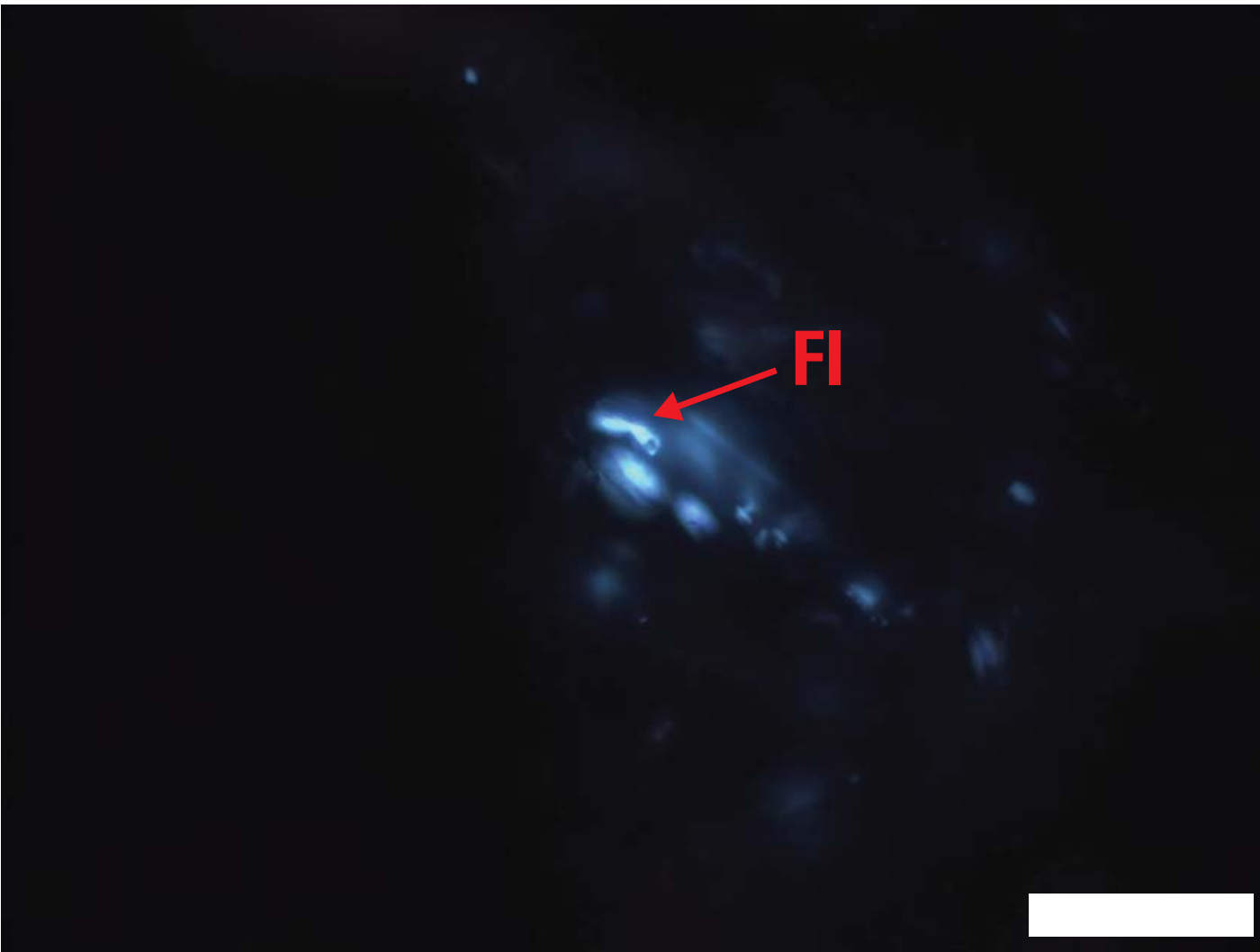

Figure 11. (A) Plane polarized light photomicrograph of two-phase (liquid and vapor)

hydrocarbon fluid inclusions (FI) within calcite. Scale bar is $50 \mu \mathrm{m}$. (B) Photomicrograph of the same field of view in UV epi-fluorescence. These hydrocarbon fluid inclusions (FI) fluoresce a blue-white color. Scale bar is $50 \mu \mathrm{m}$. 


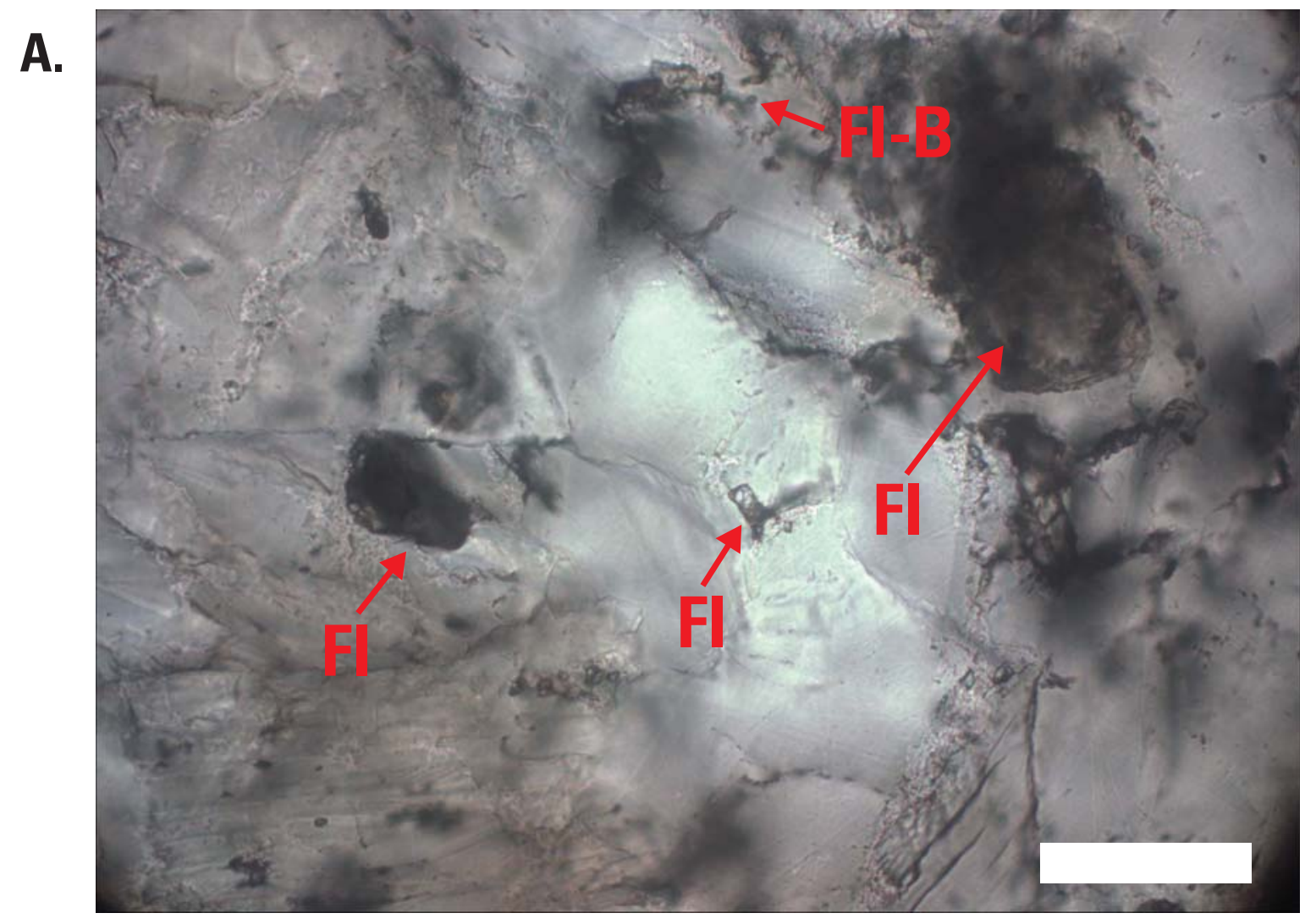

B.

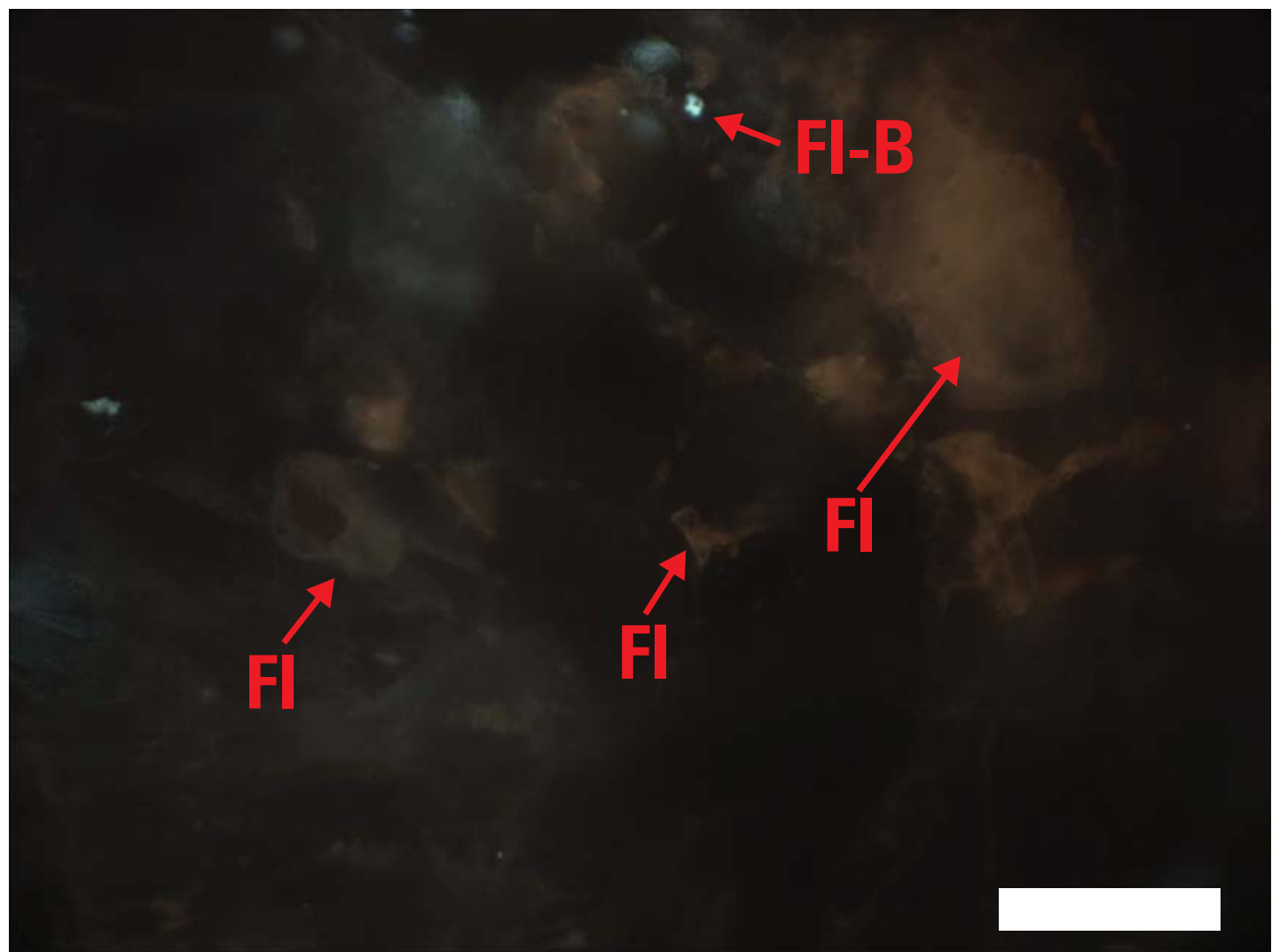

Figure 12. (A) Plane polarized light photomicrograph of hydrocarbon fluid inclusions (FI) within calcite. Scale bar is $50 \mu \mathrm{m}$. (B) Photomicrograph of the same field of view in UV epifluorescence. These hydrocarbon fluid inclusions (FI) fluoresce a muted red color. There is a single two-phase hydrocarbon inclusion that fluoresces a blue-white color (FI-B) in the top center region of the photomicrograph. Scale bar is $50 \mu \mathrm{m}$. 
A.

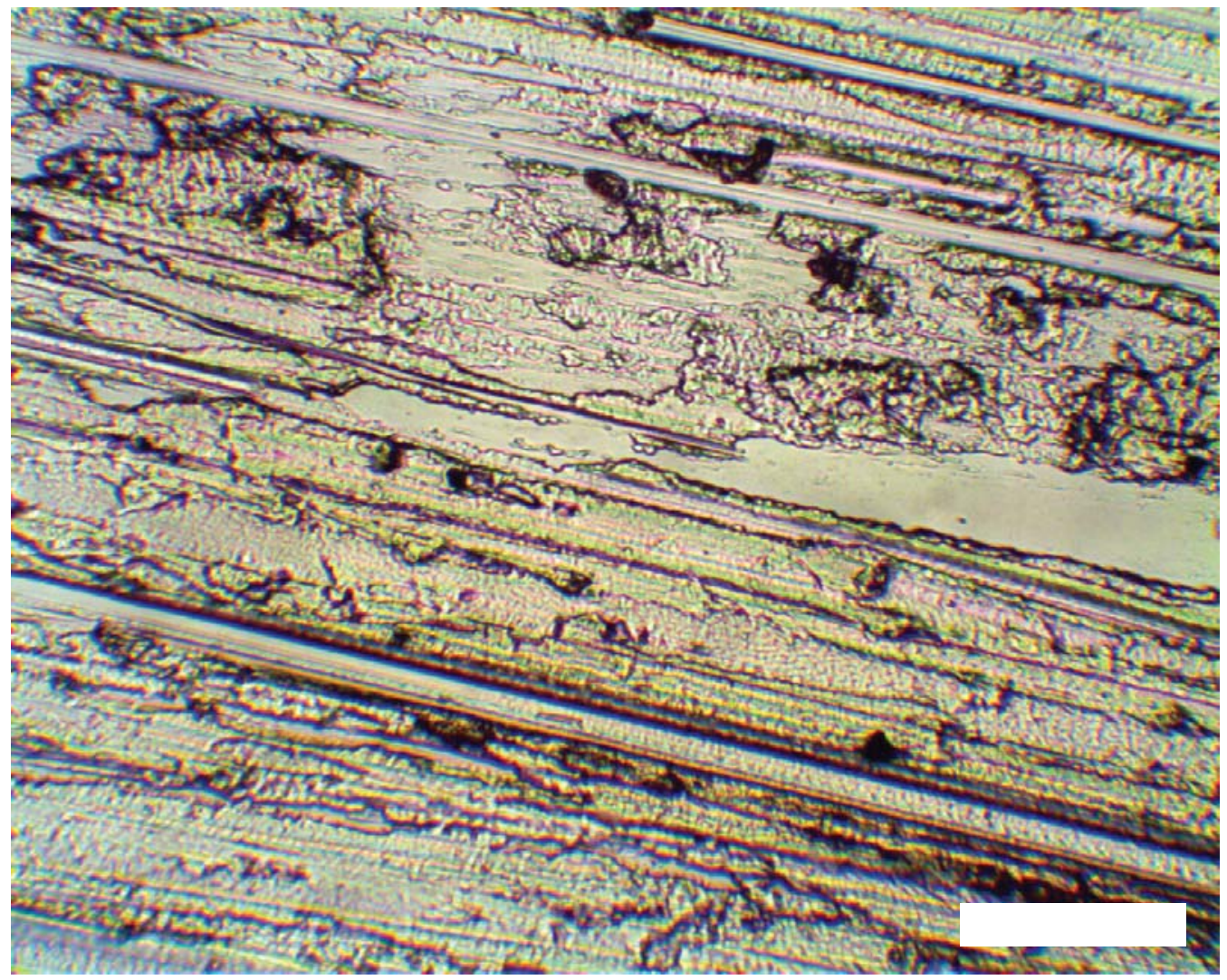

B.

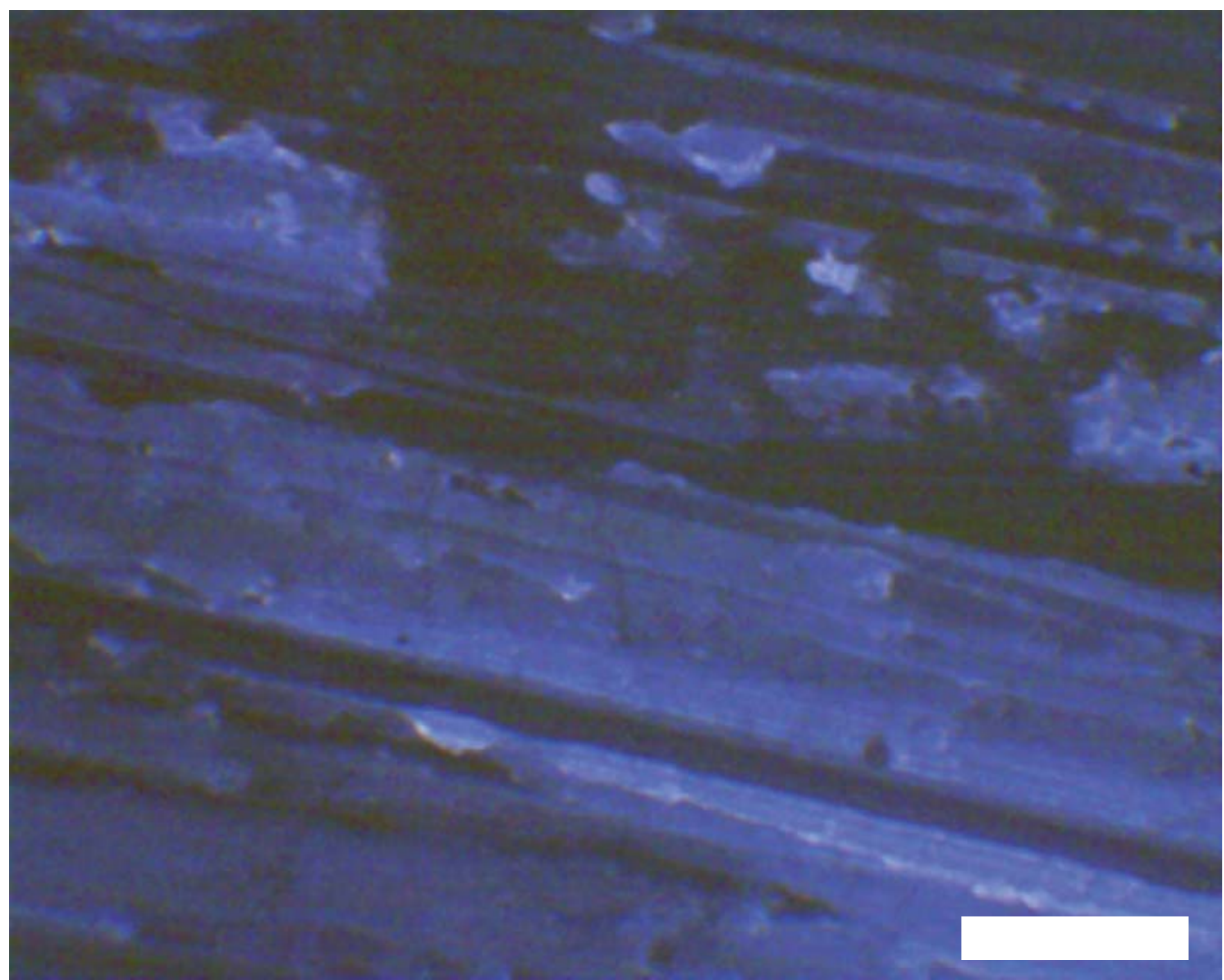

Figure 13. (A) Plane polarized light photomicrograph of a thin smear of ozokerite. The ozokerite is translucent, with a slight amber color when it is spread thinly. Scale bar is $200 \mu \mathrm{m}(B)$ Photomicrograph of the same field of view in UV epi-fluorescence. The ozokerite fluoresces a blue-white color similar to one of the hydrocarbon fluid inclusion types. Scale bar is $200 \mu \mathrm{m}$ 

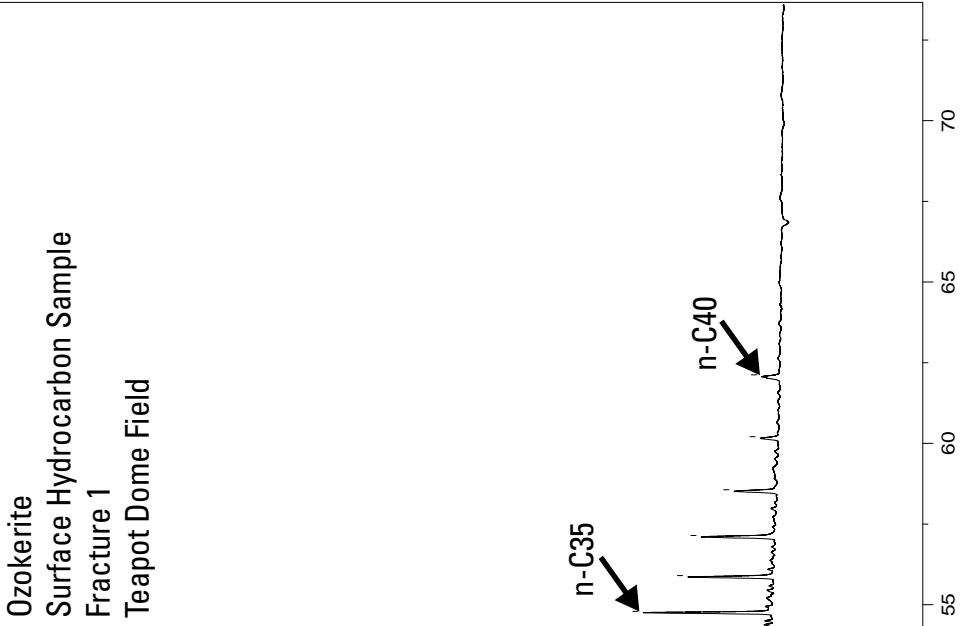

을

员 造

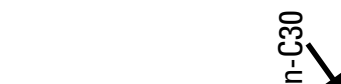

बे

हิ त

욤

욤

远

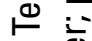

ᄃ

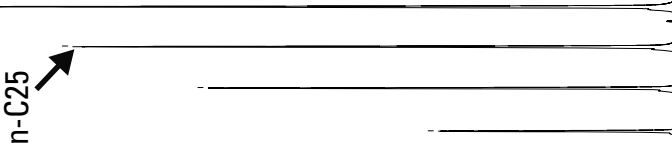

-タ⿱ 口ে

ఏ

总

证

느 은

힌

g

हิ ฏ

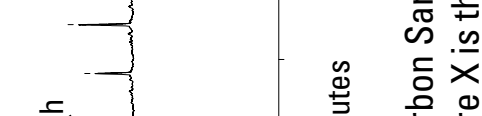

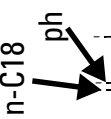

는 $\frac{0}{0}$

$\sum$ ठ

离 产 \&

흥 ब유

m

뜌

के

트음

진

至

西

Ĕ

등 은

ำ

象:

ब वे

는 응

Ф)

응

임

வ்

인

- $\quad \frac{9}{9}$ 


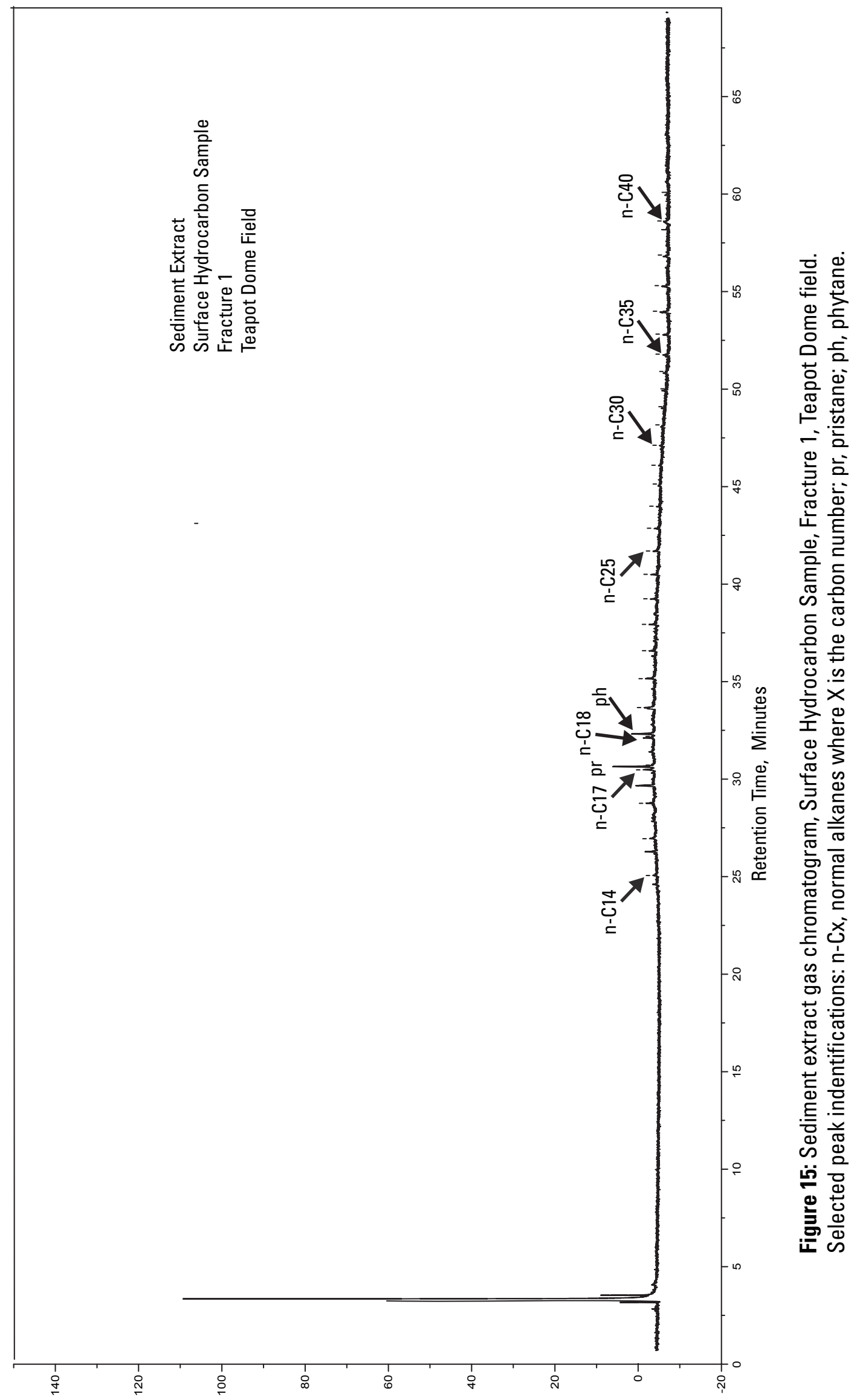

Sł|0^!!I!W -- әsuodsəy 


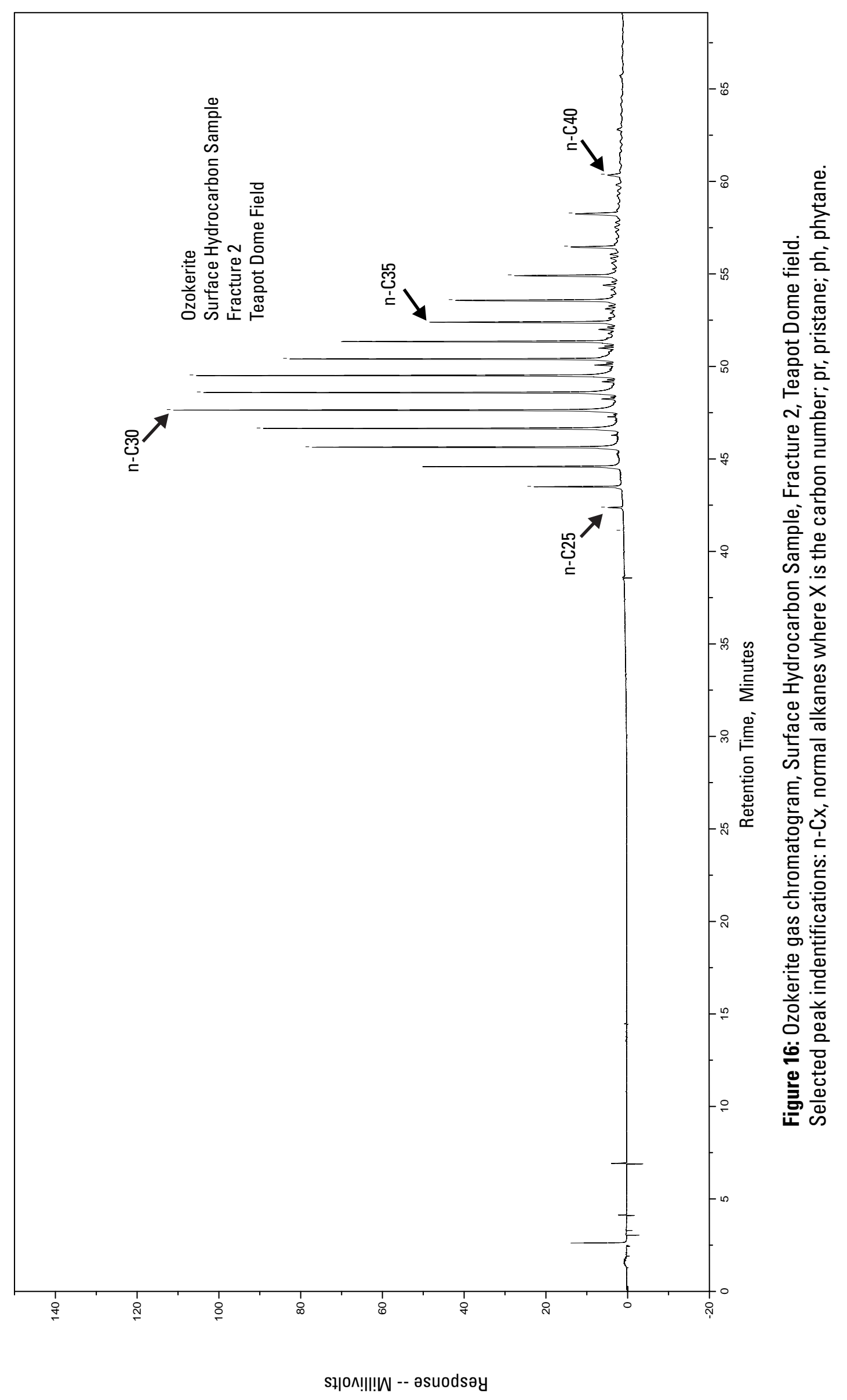




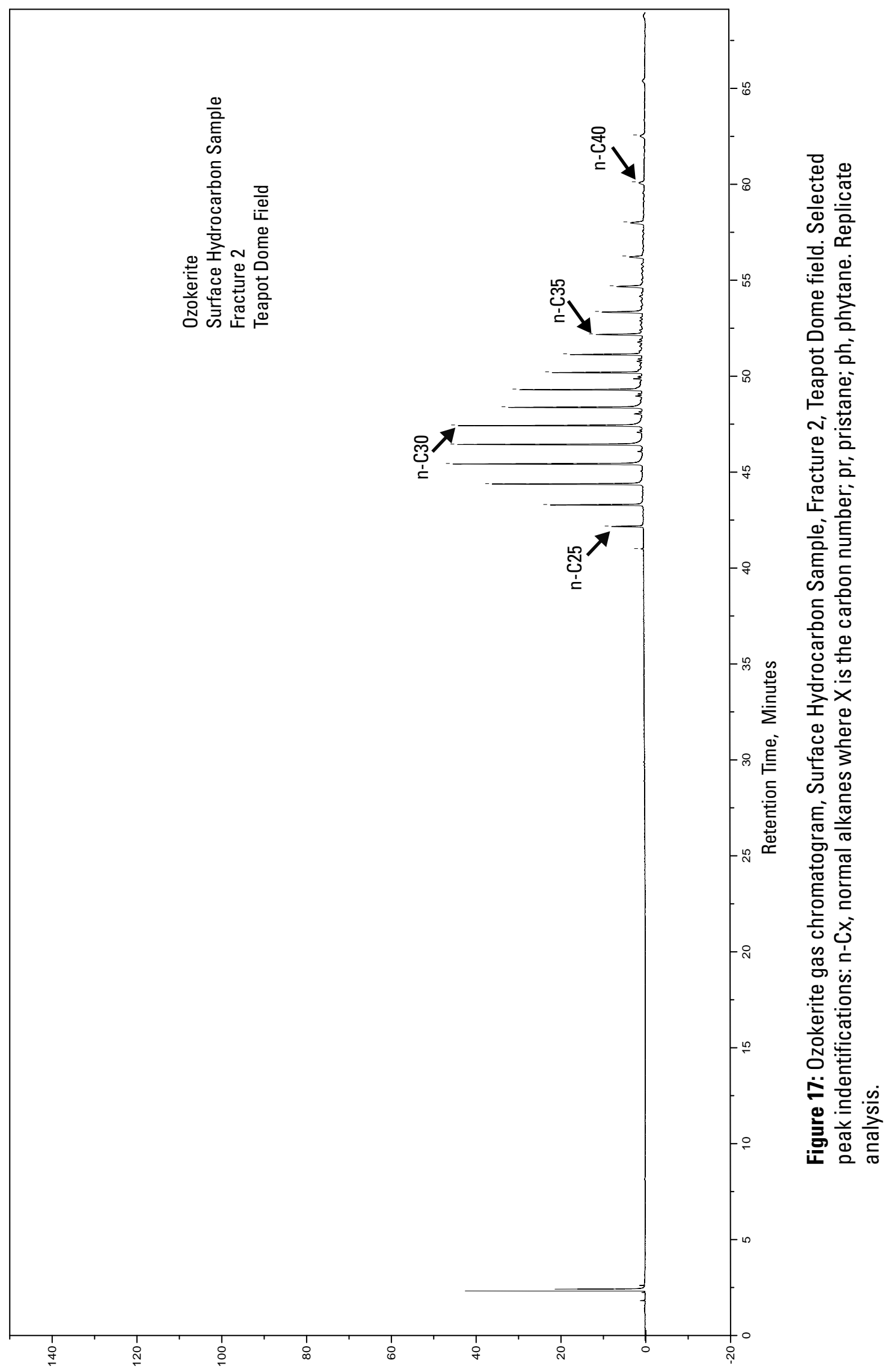

Sł|0^!!I!W -- әsuodsəy 
A.

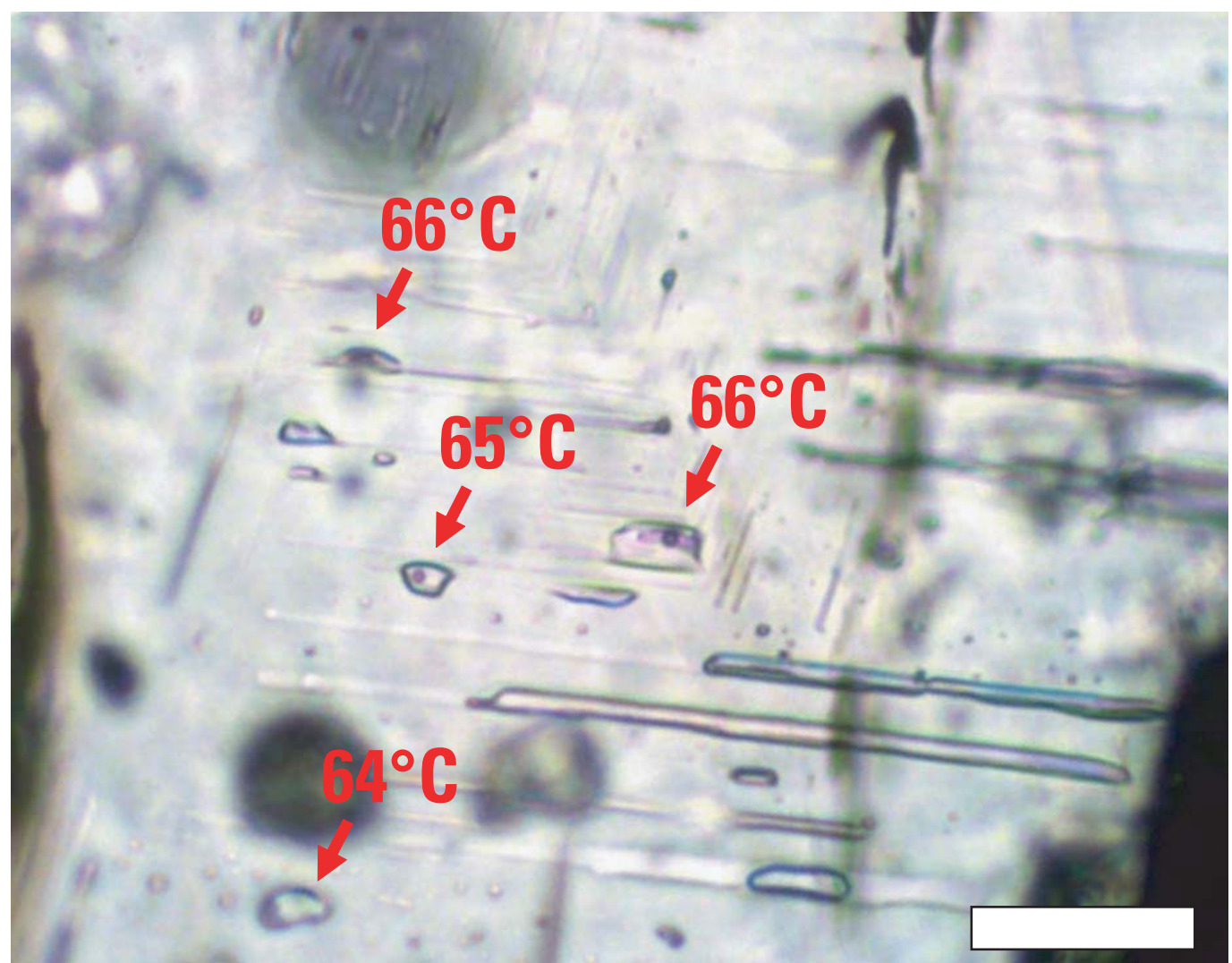

B.

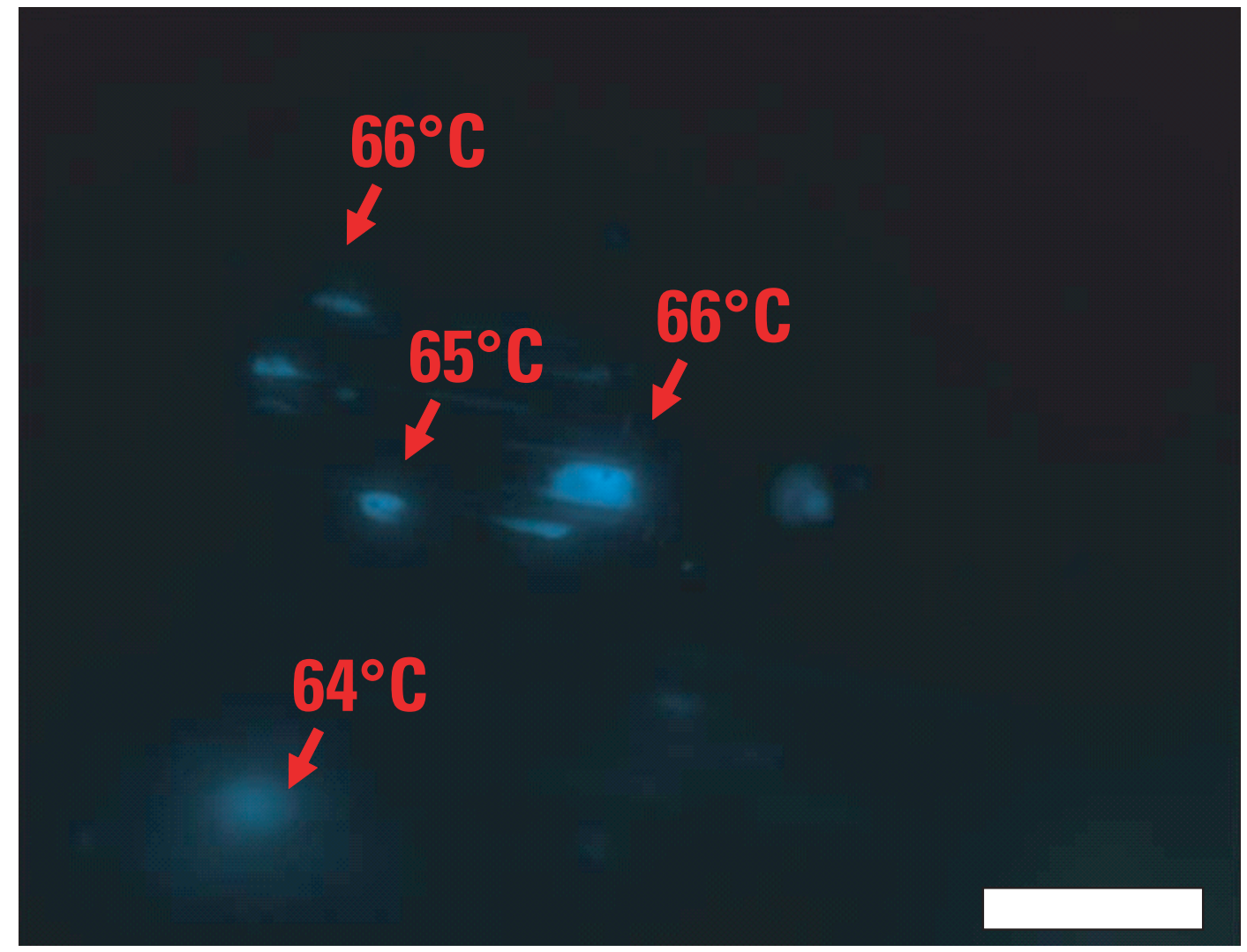

Figure 18. (A) Plane polarized light photomicrograph of fluid inclusions within calcite. Red arrows and numbers indicate homogenization temperatures of the fluid inclusions. Three other inclusions out of this field of view also homogenized to liquid at 62,62 , and 63 degrees celsius respectively. Scale bar is $25 \mu \mathrm{m}(B)$ Photomicrograph of the same field of view in UV epi-fluorescence. These hydrocarbon inclusions are two phase, and fluoresce a blue-white color. Scale bar is $25 \mu \mathrm{m}$ 